\title{
Natural Alkamides: Pharmacology, Chemistry and Distribution
}

\author{
María Yolanda Rios \\ Centro de Investigaciones Químicas, Universidad Autónoma del Estado de Morelos, \\ Col. Chamilpa, Cuernavaca, Morelos, \\ México
}

\section{Introduction}

Alkamides are a broad and expanding group of bioactive natural compounds found in at least 33 plant families. Despite the relatively simple molecular architecture of alkamides (fig. 1), these natural products show broad structural variability and an important range of biological activities, such as immunomodulatory, antimicrobial, antiviral, larvicidal, insecticidal, diuretic, pungent, analgesic, cannabimimetic and antioxidant activities. Additionally, alkamides are involved in the potentiation of antibiotics and the inhibition of prostaglandin biosynthesis, RNA synthesis and the arachidonic acid metabolism, among others.

Many plant species containing alkamides have been used in traditional medicine by different civilizations around the world. Many of the plants containing these natural products have been used in the treatment of toothaches and sore throats (Rios-Chavez et al., 2003). These compounds are present in different organs of the plant, such as roots (Heliopsis longipes, Echinaceae purpurea, Achillea wilhelmsii, Acmella oppositifolia, Asiasarum heterotropoide, Cissampelos glaberrima, etc.), leaves and stems (Aristolochia gehrtii, Phyllanthus fraternus, Amaranthus hypochondriacus, Achyranthes ferruginea, etc.), the pericarpium (Zanthoxylum piperitum and Piper spp.), the placenta of Capsicum spp., the fruits of Piper longum, the flowers of Spilanthes acmella, the seeds of the Piper species and tubers of Lepidium meyenii. It is believed that alkamides act as plant growth regulators, promoting or inhibiting the growth and formation of roots in a dose-dependent manner and showing a positive effect in plant biomass production (Campos-Cuevas, et al., 2008).

Structurally, natural alkamides commonly have an aliphatic, cyclic or aromatic amine residue, and a C8 to C18 saturated or unsaturated chain (including double or triple bonds, or both) acid, which can also be aromatic. The nature of the acid (carbon chain lengths, unsaturation level, stereochemistry, etc.) and the amine residues are characteristic of each family and genus of plants such that these characteristics serve as chemotaxonomic criteria (fig. 1). Because the nitrogen atom of alkamides is not part of a heterocyclic ring, these compounds are classified as protoalkaloids or pseudoalkaloids.

Alkamides represent a class of lipidic compounds structurally related to animal endocannabinoids. Notably, based on the structural similarity of these compounds to 
anandamide ( $N$-arachidonoylethanolamine), an endogenous cannabinoid cerebral neurotransmitter, alkamides are highly active in the central nervous system (CNS, fig. 2).<smiles>C#CC#CCC/C=C/C=C/C(=O)NCC(C)CNC(=O)/C=C/c1ccc(O)cc1</smiles>

Fig. 1. Characteristic alkamides from different plant genera.

Fig. 2. Anandamide ( $N$-arachidonoylethanolamine) structure.

In general, when alkamide-producing plants are chewed, a pungent taste is released causing itching and salivation. Chloroform is the best solvent for the extraction of alkamides, though both methanol and ethanol have also been used. Pure alkamides are sensitive to oxidation and polymerization of double and triple bonds occur during the drying, handling and storage of these compounds. Notably, alkamides are promising chemical and pharmacological entities that are useful therapeutics for the treatment of several important illnesses. This chapter describes the distribution of alkamides, the chemical aspects used to distinguish these important natural products and the pharmacological properties of the plants from which these compounds are isolated. 


\section{Aliphatic alkamides}

Plants belonging to the Asteraceae, Convolvulaceae, Euphorbiaceae, Menispermaceae and Rutaceae families specialize in the biosynthesis of alkamides with both amine and acid aliphatic residues. Chemical analysis of these species revealed that aliphatic alkamides are the major and most characteristic components of several Asteraceae plants based on the number of isolated compounds from each plant and the yield obtained for each alkamide. In contrast, Convolvulaceae, Euphorbiaceae, Menispermaceae and Rutaceae families produce alkamides along with other types of natural products, resulting in alkamides being the minor components.

\subsection{Alkamides from the Asteraceae family}

The Asteraceae family is characterized by the accumulation of aliphatic alkamides. Aaronsohnia, Achilea, Acmella, Anacyclus, Artemisia, Echinaceae, Heliopsis, Spilanthes, Salmea, Sanvitalia and Wedelia are genera that belong to this alkamide-producing family. These genera share the biogenetic capacity to combine C8 to C18 (with exception of C17) olefinic and acetylenic acid residues with the more widespread $\mathrm{N}$-isobutyl, $\mathrm{N}$-2-methylbutyl, $\mathrm{N}$ phenethyl and cyclic amines [piperidinyl (piperidide), 2,3-dehydro-piperidinyl (piperideide), pyrrolidinyl and pyrrolidyl]. However, other minor amides including N-4methylbutyl, $N$-tyramidyl and $O$-methyl-tyramidyl residues have also been found (fig. 3 ).

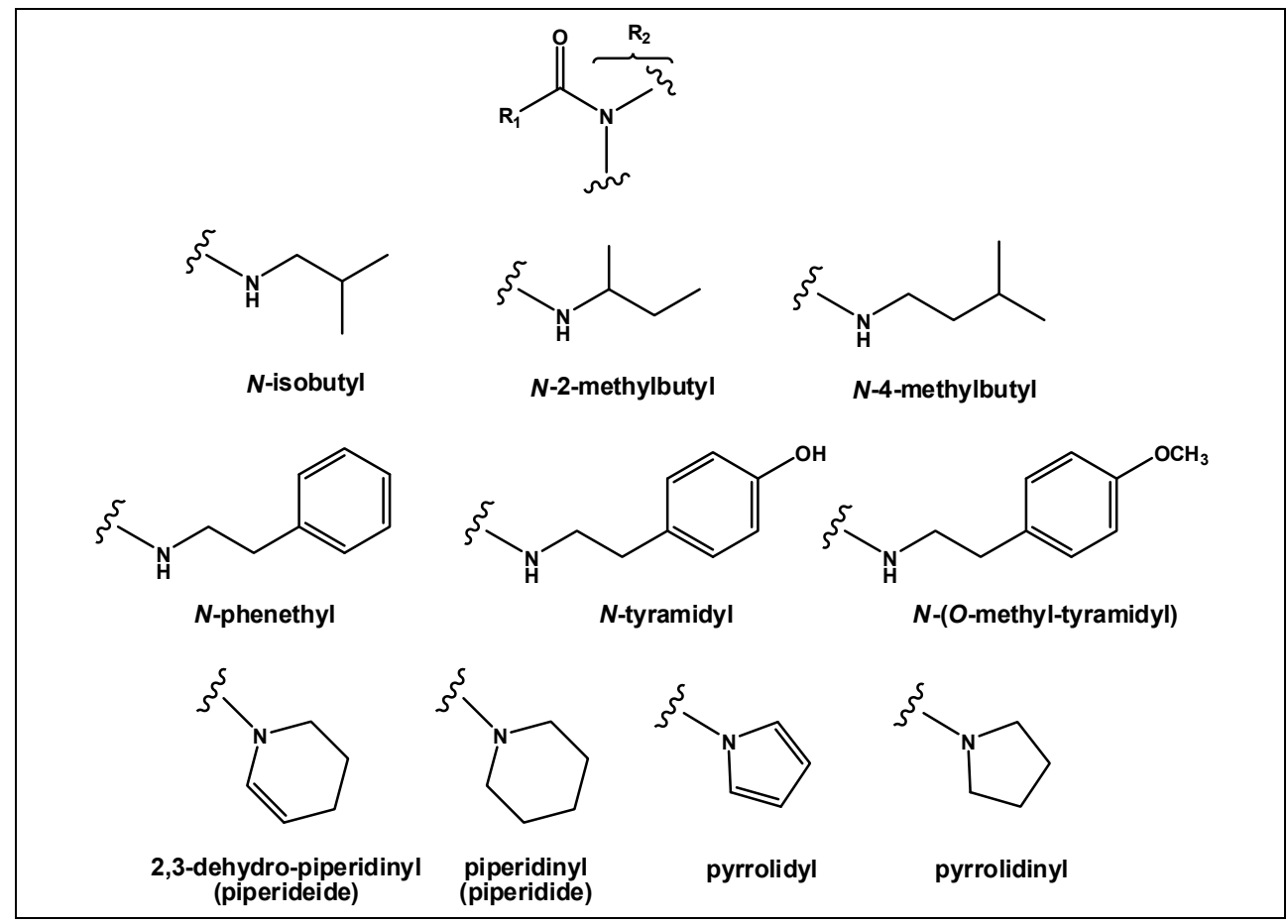

Fig. 3. Amine residues $\left(R_{2}\right)$ of aliphatic alkamides from the Asteraceae family. 
Currently, the most commonly found alkamides in the Asteraceae family include a C10, C11 and C12 long chain residue acids, which represent approximately $72 \%$ of aliphatic alkamides isolated from this family. The second most important group of these natural products includes C14 and C18 long chain residue acids, constituting approximately $13 \%$ of Asteraceae alkamides. Most phytochemical and pharmacological studies have been conducted with Achillea, Acmella, Sphilantes, Echinaceae and Heliopsis genera, which will be discussed in subsequent sections.

\subsubsection{Achillea genus}

The occurrence of alkamides with cyclic amide moieties is confined to the Anthemideae tribe, being Achillea species especially rich in both pyrrolidides and piperidides and their corresponding dehydroderivatives. Apart from the more widespread isobutylamides, this genus is characterized by the frequent occurrence of saturated and unsaturated 5- and 6-ring amides (Greger et al., 1987a, 1987b). The accumulation of amides with characteristic olefinic and acetylenic patterns is characteristic of this genus. These amides are mainly accumulated in the subterranean parts of these plants (table 1).

\subsubsection{Acmella genus}

A name frequently used in folk medicine for species containing alkamides is "the tooth herb". These plants exhibit analgesic properties and are frequently used as odontologic agents. For example, Acmella decumbens roots have a pungent taste and when chewed a numbing sensation is felt on the tongue. Acmella radicans is another species also used for the treatment of toothache (Rios-Chavez et al., 2003).

Alkamides from the Acmella genus consist of an N-isobutyl, N-2-methylbutyl or N-phenethyl amine and C8 to C12 acid residues. Of the seven Acmella species that have been chemically analyzed, four species have been observed to produce affinin (spilanthol, $\mathrm{N}$-isobutyl$2 E, 6 Z, 8 E$-decatrienamide, 70), an alkamide with established analgesic properties (Rios et al., 2007). Several affinin analogues are present in extracts from these Acmella species (see table 1 ), which probably contribute to the analgesic sensation induced by these plants.

\subsubsection{Spilanthes genus}

For years Spilanthes acmella has been used as traditional folk medicine to treat toothaches, stammering, and stomatitis. Previous studies have demonstrated the diuretic, antibacterial, and anti-inflammatory activities of Spilanthes acmella. Spilanthol (70), the main alkamide isolated from this plant, exhibits antiseptic activity. Additionally, spilanthol (70) is involved in immune stimulation and the attenuation of the inflammatory responses in murine RAW 264.7 macrophages (Wu et al., 2008).

\subsubsection{Echinaceae genus}

Echinacea is a native herb from North America and Europe that is used as an immunostimulant. Extracts from the Echinacea species are widely used due to the strong belief that the components of the extract stimulate the immune system and help to prevent infections, colds, respiratory infections and influenza. However, the clinical efficacy of this 


\begin{tabular}{|c|c|c|c|c|c|c|c|}
\hline 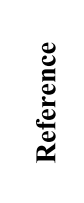 & 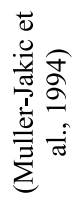 & 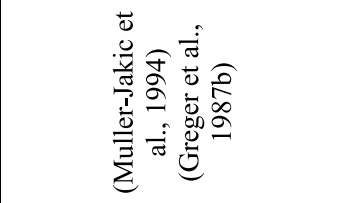 & 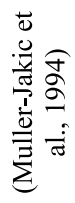 & 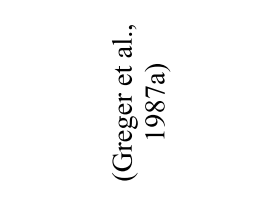 & 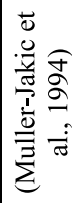 & 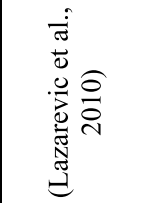 & 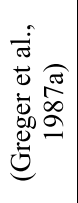 \\
\hline$\tilde{q}$ & 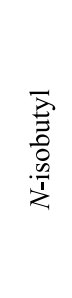 & 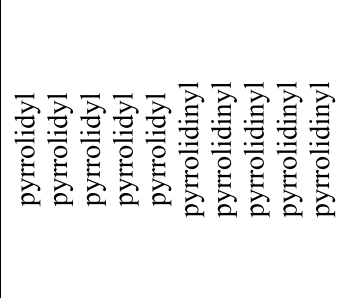 & 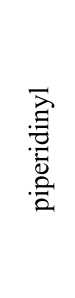 & 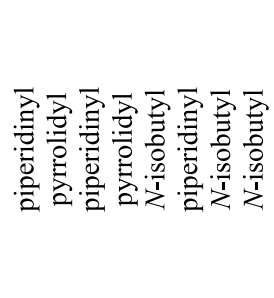 & 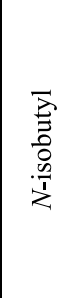 & 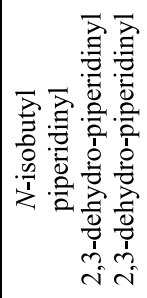 & 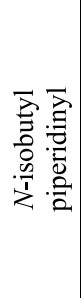 \\
\hline 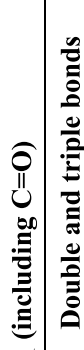 & 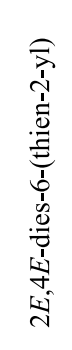 & 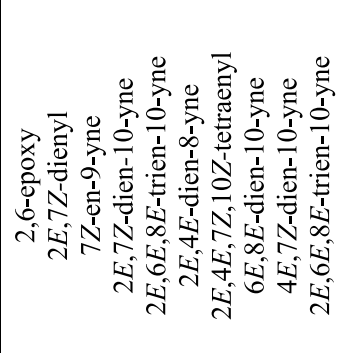 & 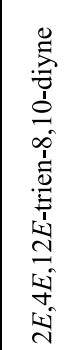 & 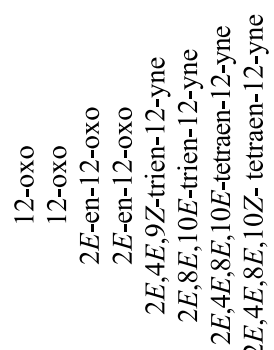 & 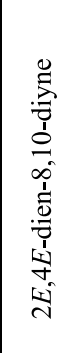 & 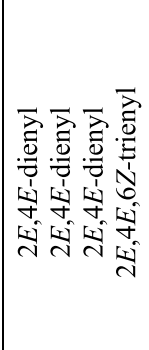 & 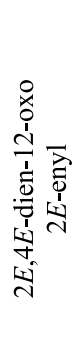 \\
\hline שี & $\stackrel{\circ}{U}$ & 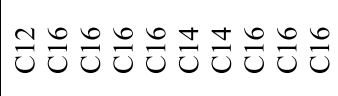 & $\vec{U}$ & 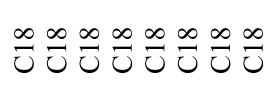 & $\bar{u}$ & 을을을 & $\frac{n}{u} \frac{\infty}{U}$ \\
\hline 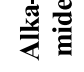 & - & netanosal $=$ & 2 & のேニニッの゚ & $\bar{\sim}$ & สึั่ & 오 \\
\hline 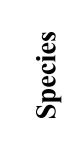 & 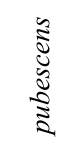 & 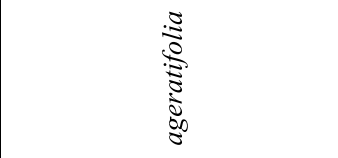 & 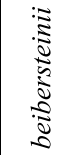 & 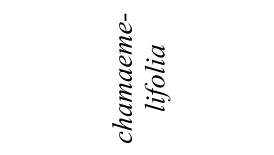 & 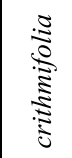 & 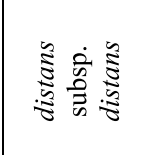 & 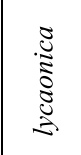 \\
\hline 气ू & 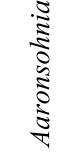 & \multicolumn{6}{|c|}{ 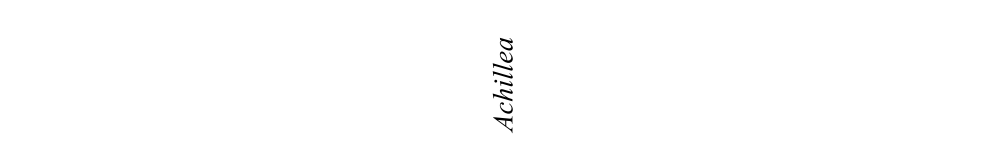 } \\
\hline$\stackrel{\mathscr{B}}{\Xi}$ & & & & 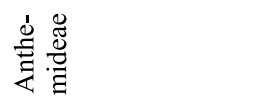 & & & \\
\hline
\end{tabular}




\begin{tabular}{|c|c|c|c|c|}
\hline 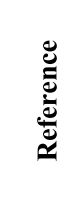 & & 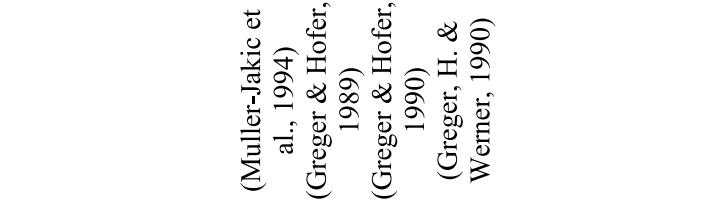 & 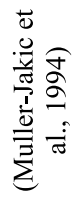 & 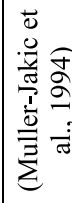 \\
\hline$\simeq$ & 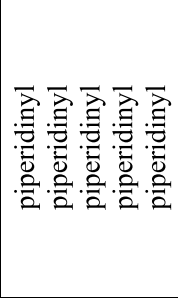 & 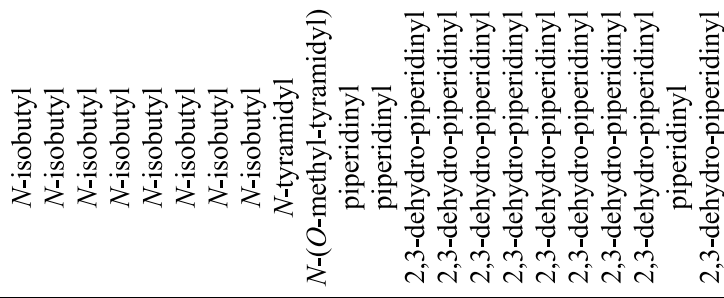 & 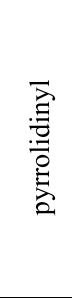 & 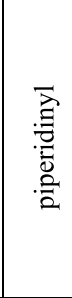 \\
\hline \multirow[t]{2}{*}{ 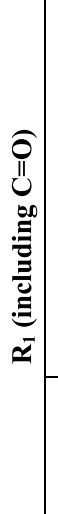 } & 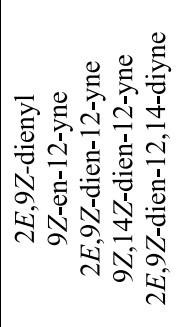 & 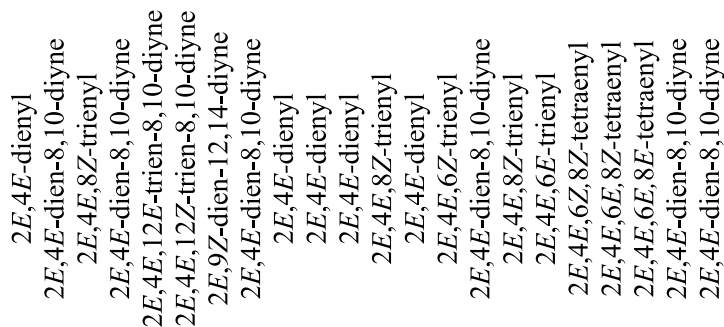 & 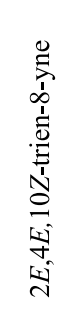 & 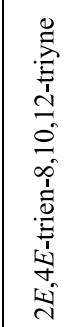 \\
\hline & $\stackrel{\infty}{\circlearrowright} \stackrel{\infty}{\circlearrowright} \stackrel{\infty}{\circlearrowright} \stackrel{\infty}{\circlearrowright} \frac{\infty}{\circlearrowright}$ & 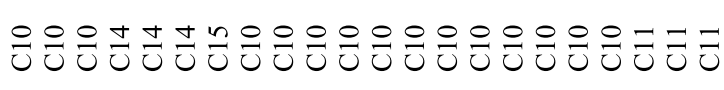 & $\stackrel{\Delta}{U}$ & $\stackrel{m}{u}$ \\
\hline 产尝 & 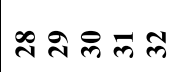 & 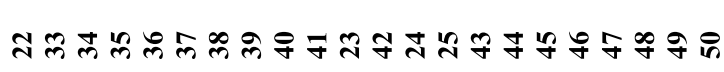 & n & ก \\
\hline 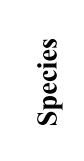 & & 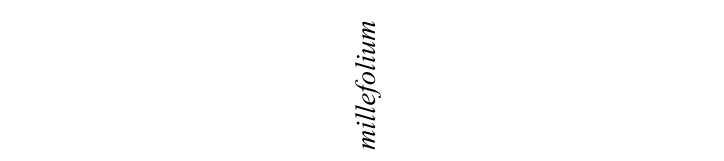 & $\Xi$ & 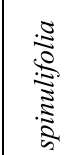 \\
\hline \multicolumn{5}{|l|}{$\stackrel{\mathscr{E}}{\Xi}$} \\
\hline : & & & & \\
\hline
\end{tabular}




\begin{tabular}{|c|c|c|c|c|c|c|c|c|}
\hline 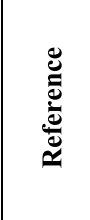 & 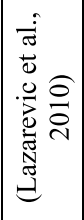 & 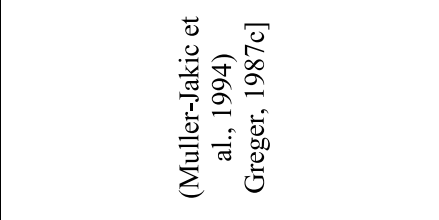 & 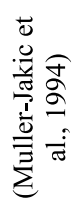 & 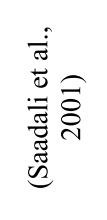 & 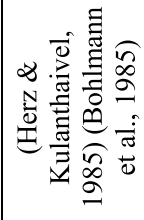 & 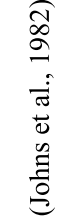 & 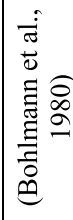 & 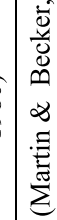 \\
\hline$\simeq$ & 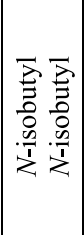 & 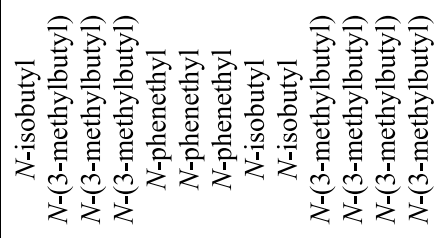 & 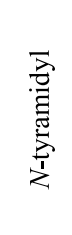 & 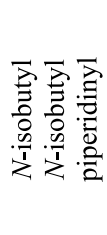 & 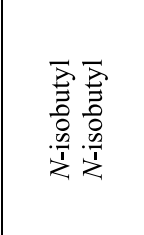 & 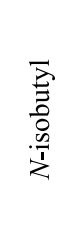 & 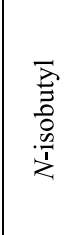 & $\mid$\begin{tabular}{c}
3 \\
$\vdots$ \\
0 \\
0 \\
.02 \\
\hdashline \\
$z$
\end{tabular} \\
\hline 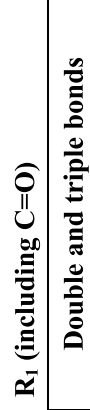 & 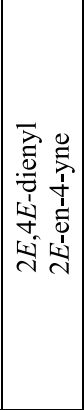 & 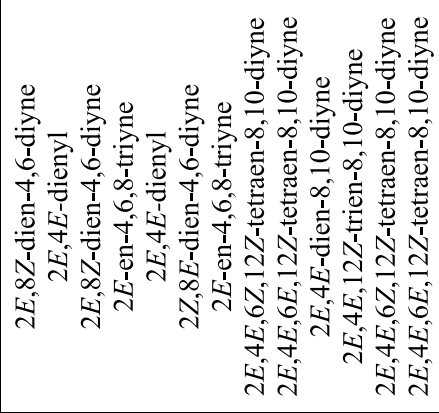 & 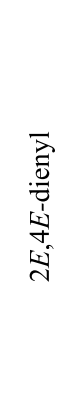 & 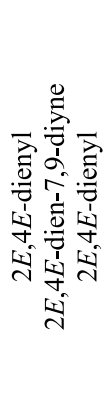 & 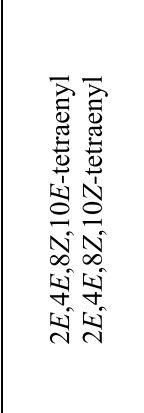 & 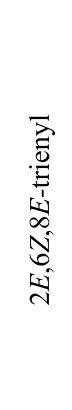 & 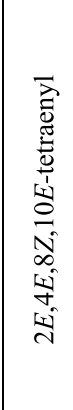 & 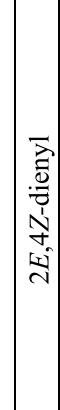 \\
\hline 嫣 & 응ㅇ & 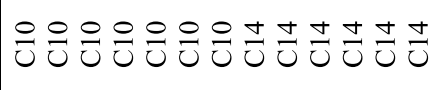 & $\stackrel{\circ}{0}$ & 을이 & 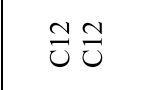 & $\stackrel{0}{u}$ & $\stackrel{1}{U}$ & $\infty$ \\
\hline 菷莺 & $\approx$ in & 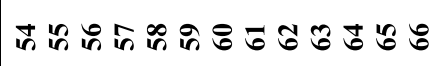 & P & $\approx 5 \approx$ & $: 8$ & R & $\stackrel{\infty}{\infty}$ & $F$ \\
\hline 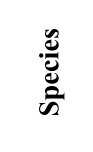 & 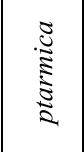 & 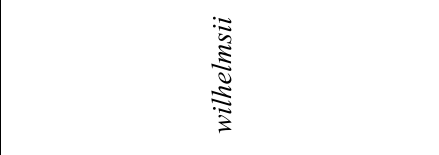 & 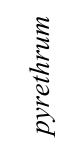 & 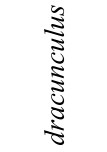 & 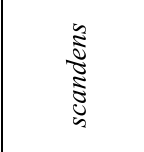 & 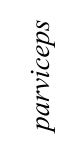 & శี & 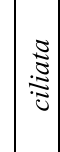 \\
\hline 苞 & & & 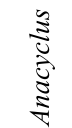 & 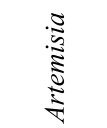 & हूँ & 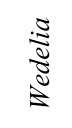 & ఫे & \\
\hline : & & & & & 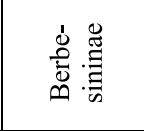 & 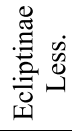 & 毛 & 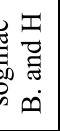 \\
\hline
\end{tabular}




\begin{tabular}{|c|c|c|c|c|c|c|}
\hline 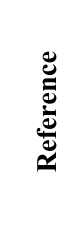 & 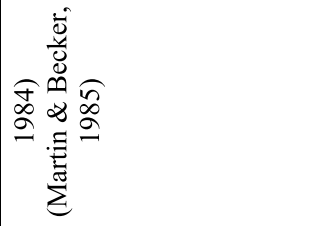 & 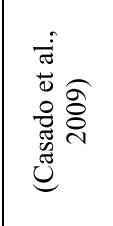 & 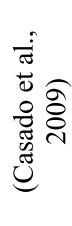 & 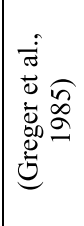 & 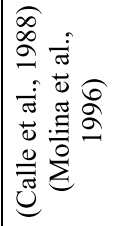 & 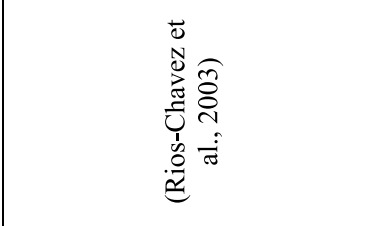 \\
\hline$\underline{\sim}$ & 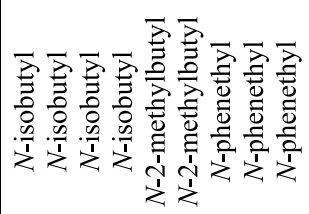 & 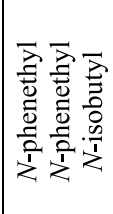 & 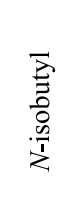 & 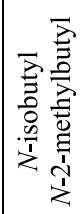 & 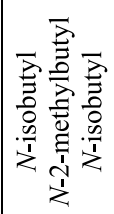 & 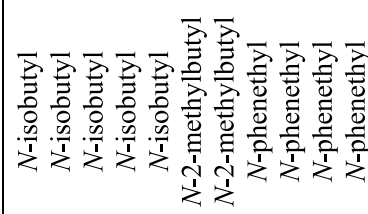 \\
\hline \multirow[t]{2}{*}{ 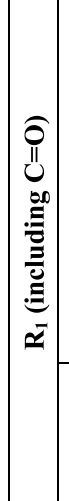 } & 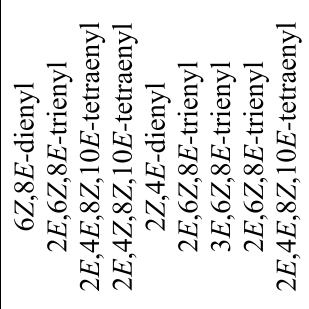 & 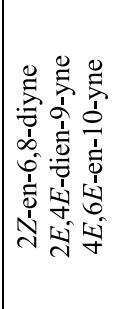 & 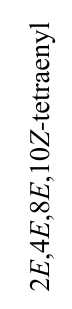 & 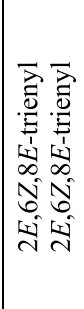 & 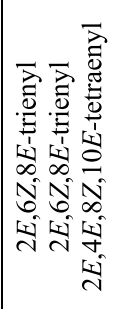 & 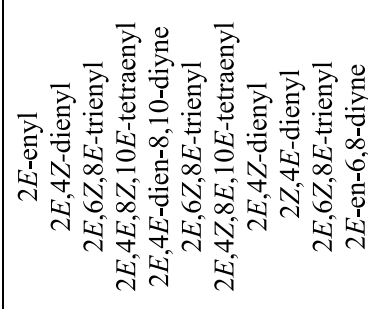 \\
\hline & 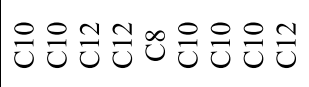 & ชํㅡㄹ & $\stackrel{1}{U}$ & 을 & 을ำ & 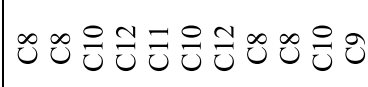 \\
\hline$\stackrel{\frac{1}{\tilde{y}}}{\frac{1}{2}}$ & ペロ゚ネパト゚ & 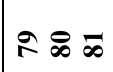 & $\infty$ & $8 \div$ & Rパ & $\infty \infty$ \\
\hline 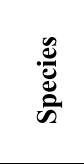 & & 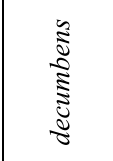 & 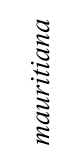 & $\begin{array}{l}\tilde{J} \\
\frac{8}{0} \\
\frac{0}{0}\end{array}$ & 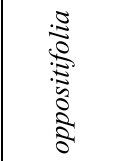 & 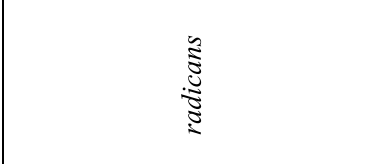 \\
\hline \multicolumn{7}{|l|}{ 氖 } \\
\hline 串 & & & & & & \\
\hline
\end{tabular}




\begin{tabular}{|c|c|c|c|c|}
\hline 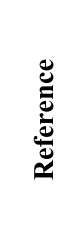 & & 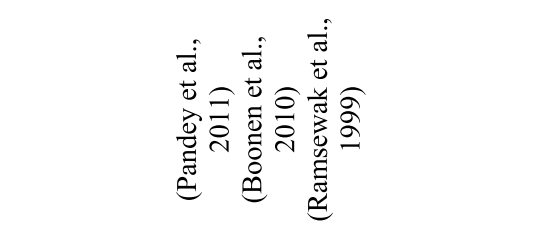 & 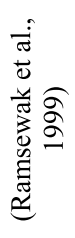 & 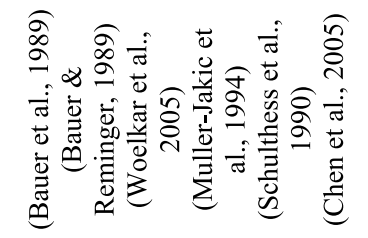 \\
\hline$\widetilde{\imath}$ & 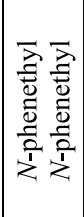 & 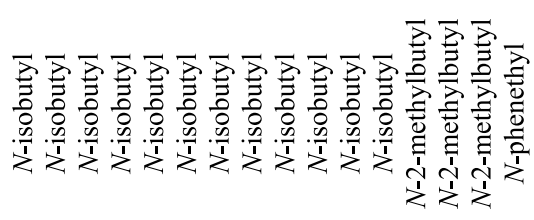 & 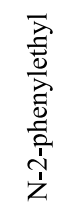 & 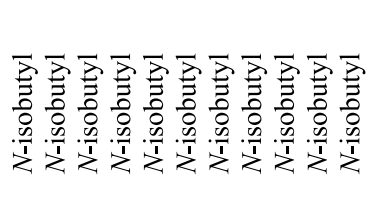 \\
\hline 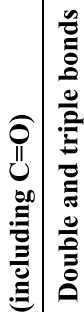 & 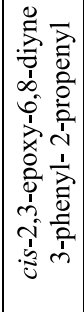 & 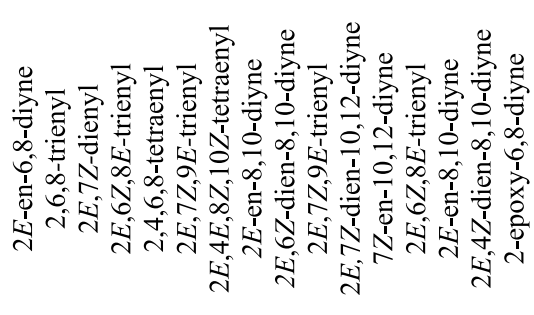 & 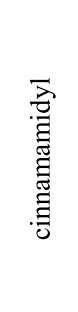 & 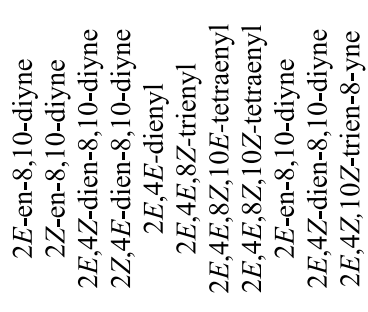 \\
\hline Uี & Oc & 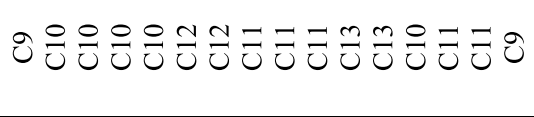 & తి & 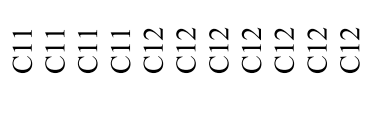 \\
\hline 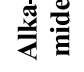 & के Д & 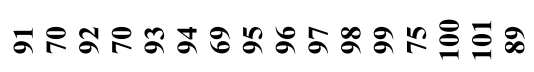 & $\tilde{气}$ & 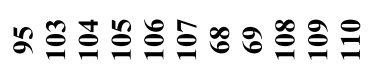 \\
\hline 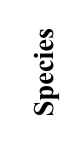 & & $\begin{array}{l}\text { তัँ } \\
\text { हुँ }\end{array}$ & 胥 & 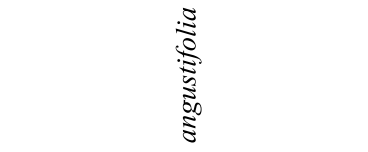 \\
\hline 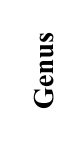 & & $\frac{\sqrt{5}}{\sqrt[5]{5}}$ & & 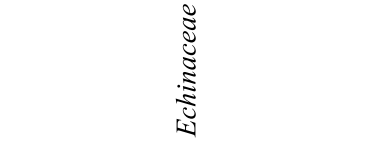 \\
\hline है & & & & 咅尝 \\
\hline
\end{tabular}




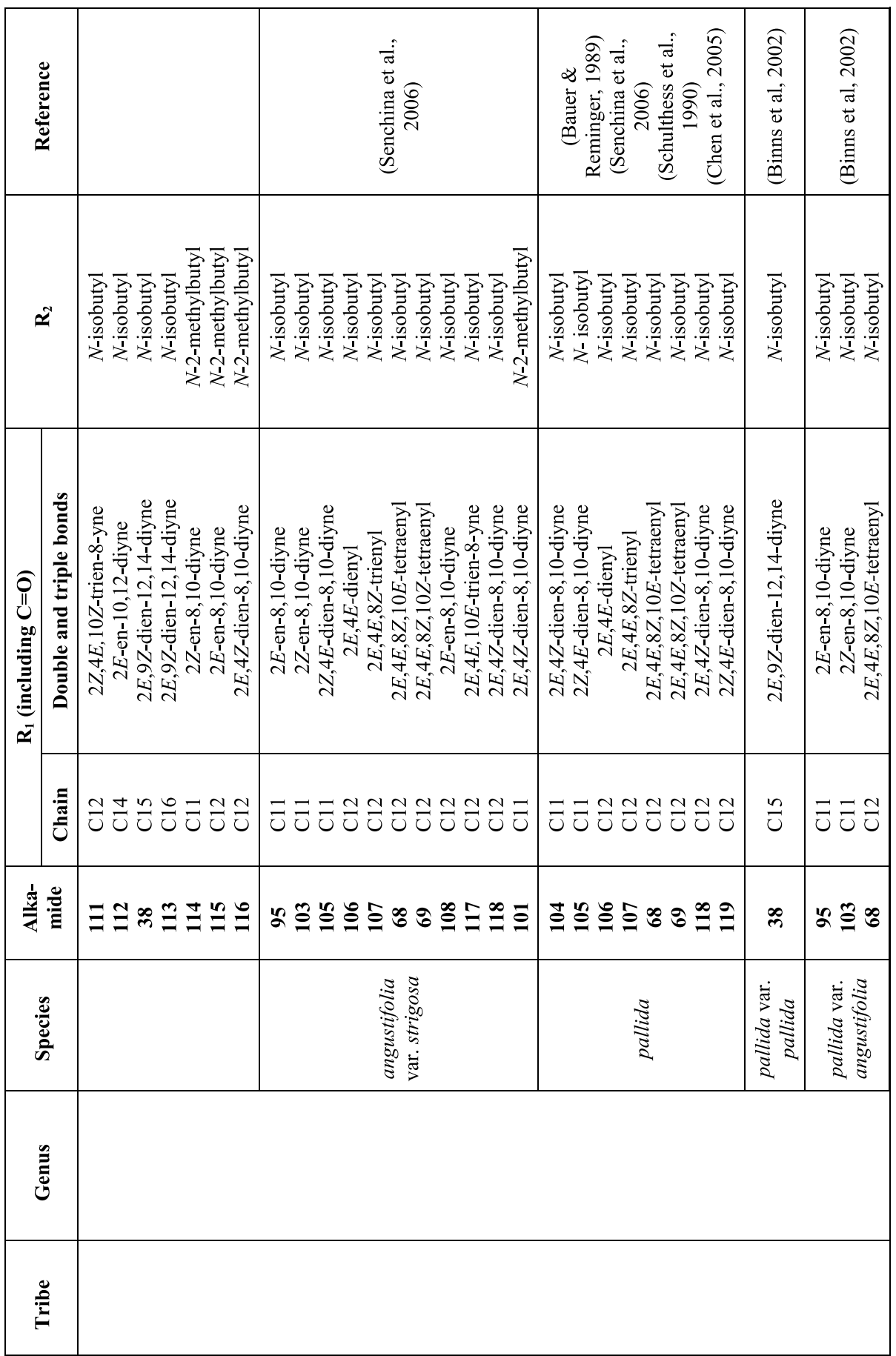




\begin{tabular}{|c|c|c|c|c|c|}
\hline 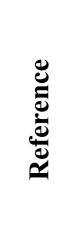 & & 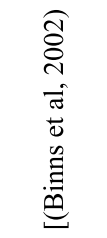 & 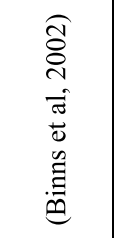 & 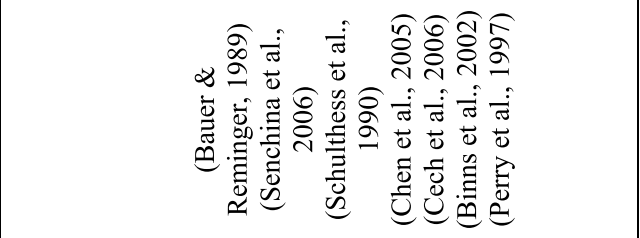 & 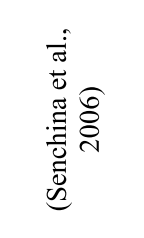 \\
\hline$\widetilde{\simeq}$ & 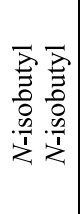 & 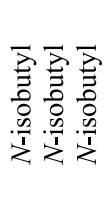 & 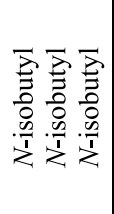 & 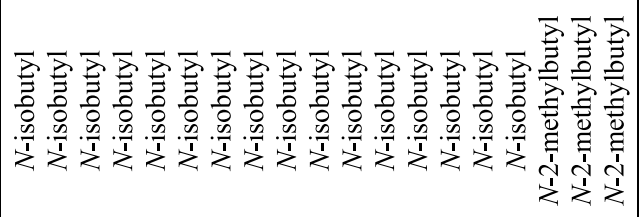 & 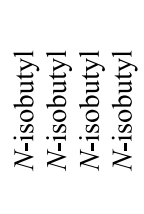 \\
\hline \multirow[t]{2}{*}{ 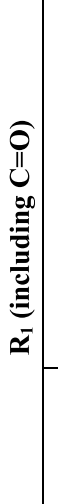 } & 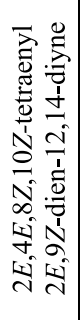 & 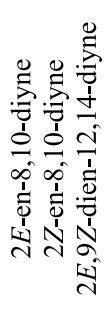 & 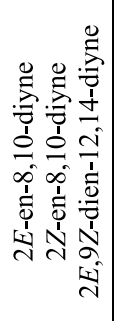 & 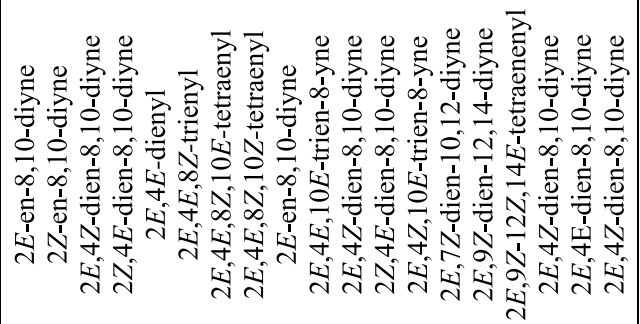 & 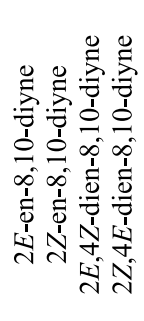 \\
\hline & $\cong \curvearrowleft$ & $\Xi \Xi \check{\circlearrowright}$ & 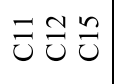 & 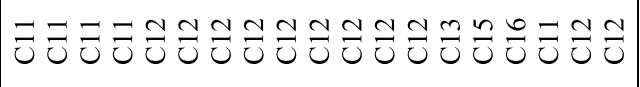 & $\bar{u} \bar{u} \bar{u} \bar{u}$ \\
\hline 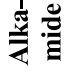 & $\hat{\sigma}_{\infty}^{\infty}$ & ূू气̊ & 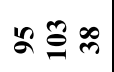 & 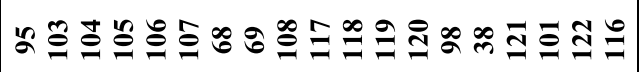 & 次气苍气 \\
\hline 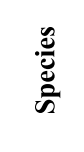 & & 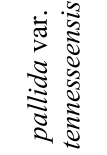 & 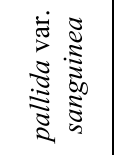 & 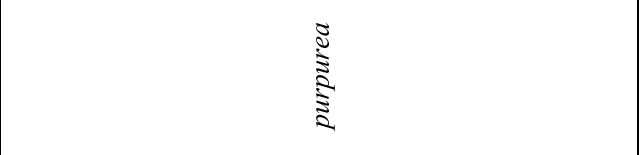 & 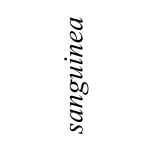 \\
\hline \multicolumn{6}{|l|}{ 咅 } \\
\hline$\stackrel{?}{E}$ & & & & & \\
\hline
\end{tabular}




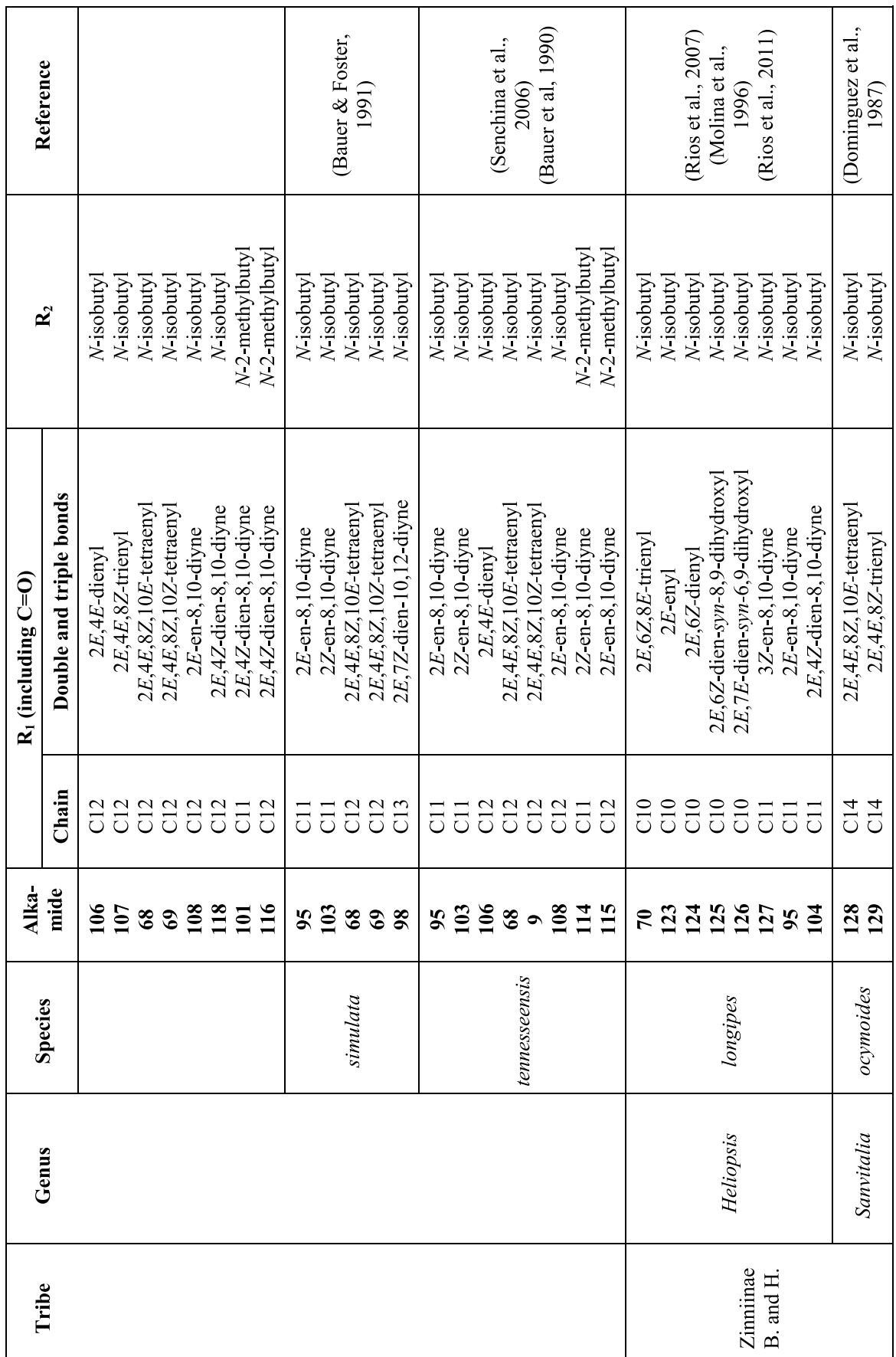

Table 1. Alkamides from the Asteraceae family. 
agent has not been proven. E. angustifolia, E. pallida and E. purpurea are three species of Echinacea that are used in commercial preparations with reported alkamide profiles. These species contain complex mixtures of alkamides that are good chemotaxonomic characters (table 1). The major alkamides in E. purpurea roots are the C12-2,4-diene and C12-2,4-dienediyne type, while the $\mathrm{C} 11$ diene-diynes were highest in vegetative stems (Binns et al., 2002). E. angustifolia roots are characterized by the presence of di-, tri- and tetraenes in coexistence with mono- and diynes, all of them with variable insaturation degree at the C2, C4, C9 or C10 position. In E. pallida, the major compounds are polienes (also di-, tri- and tetraenes) and diynes (C2 or $\mathrm{C} 2$ and $\mathrm{C} 4$ unsaturated)

Lipophilic alkamides from Echinacea show immunostimulatory activity and have been used for the treatment of cold, flu, respiratory infections and inflammations, making a considerable contribution to the activities attributed to Echinaceae plants (Bauer, 1989a, $1989 b, 1990,1991)$. Studies on the mechanisms of action of the immunomodulatory activity of Echinacea have indicated that alkylamides can act as cannabinomimetics. Endogenous ligands for cannabinoid receptors such as anandamide (fig. 2), an animal alkamide that shares structural similarity with the Echinacea alkylamides, can bind to CB2 cannabinoid receptors (LaLone et al., 2010). The cannabinoid receptors CB1 and CB2 have been implicated in the modulation of the CNS and the inflammatory response. CB1 receptors are present in neurons from the central and peripheral nervous system and are concentrated in the brain. CB2 receptors are mainly present in immune cells, such as macrophages.

\subsubsection{Heliopsis genus}

Heliopsis longipes is a Mexican plant that was broadly used by the Náhuatl civilization as flavoring in food preparation. The stems of this climber are used in traditional medicine as a condiment, buccal anesthetic, analgesic in pain toothache, antiparasitic, anti-inflammatory and antiulcerative agent and to prepare homemade insecticides that, similar to pyrethrins, are toxic and exhibit paralyzing effects. Chewing of a little piece of the Heliopsis longipes stem results in intense salivation and a local analgesic effect (Molina et al., 1996). An ethanolic extract of this plant exhibited antinociceptive effects on acute thermal and chemical inflammation induced nociception in mice with a mechanism partly linked to the lipoxygenase and/or cyclooxygenase systems (Cariño-Cortés et al., 2010). This extract exhibited synergistic interactions with diclofenac in the Hargreaves model of thermal hyperalgesia (Acosta-Madrid et al., 2009). Various unsaturated aliphatic alkamides have also been identified and characterized from the roots of this plant (table 1), such as affinin (70), its most abundant and bioactive alkamide. The analgesic activity of affinin was determined by measuring the release of GABA in mice brain slices (Rios et al., 2007). Furthermore, dosedependent antinociceptive effects have been observed to be a result of the activation of opiodergic, serotoninergic and GABAergic systems (Déciga-Campos et al., 2010).

\subsection{Aliphatic alkamides from other plant families}

Convolvulaceae, Euphorbiaceae, Menispermaceae and Rutaceae are other plant families that produce aliphatic alkamides. $\mathrm{N}$-isobutyl, 2'-hydroxy- $\mathrm{N}$-isobutyl, $\mathrm{NH}_{2}$ and pyrrolidinyl amine residues have been identified in the structures of alkamides isolated from these plants (table 2). 


\begin{tabular}{|c|c|c|c|c|c|c|c|c|}
\hline & 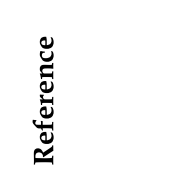 & \multicolumn{2}{|l|}{ 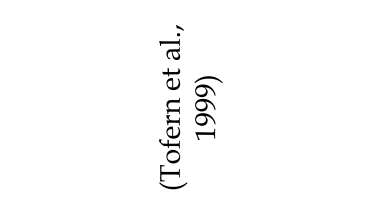 } & 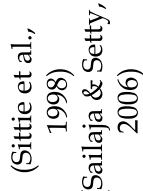 & \multicolumn{4}{|c|}{ 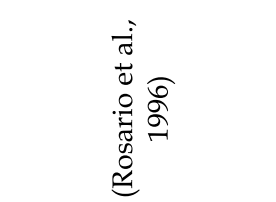 } \\
\hline & $\approx$ & 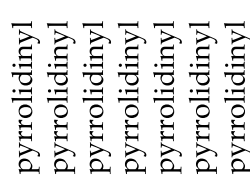 & 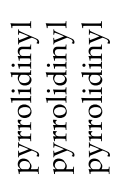 & 要耘 & 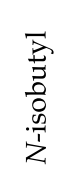 & $\begin{array}{l}\overrightarrow{3} \\
\frac{1}{3} \\
0 \\
0 \\
.09 \\
2 \\
Z\end{array}$ & $\begin{array}{l}\overrightarrow{2} \\
\frac{1}{5} \\
0 \\
0 \\
.0 \\
z \\
Z\end{array}$ & $\begin{array}{l}\overrightarrow{2} \\
\frac{1}{3} \\
0 \\
0 \\
\frac{0}{1} \\
2\end{array}$ \\
\hline \multirow[t]{2}{*}{$\approx$} & 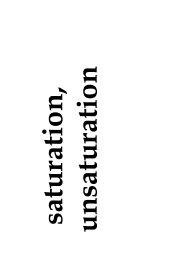 & 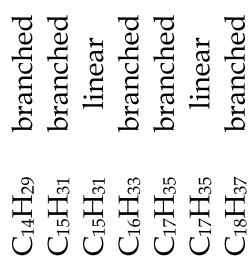 & 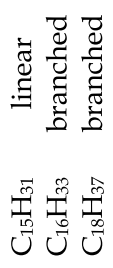 & 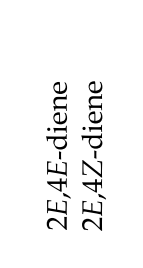 & 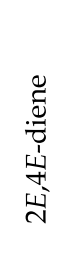 & 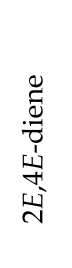 & $\begin{array}{c}\underset{d}{0} \\
\stackrel{1}{N} \\
\text { N }\end{array}$ & 1 \\
\hline & 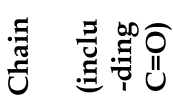 & 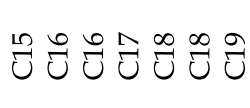 & 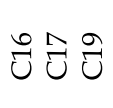 & \& & ن & 이 & 임 & 엄 \\
\hline \multicolumn{2}{|r|}{ 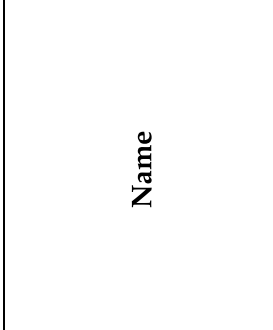 } & 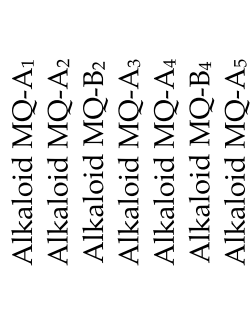 & 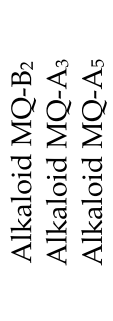 & 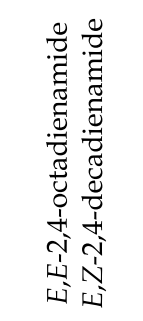 & \multicolumn{4}{|c|}{ 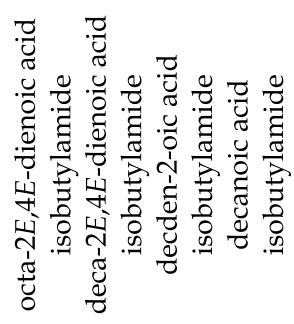 } \\
\hline & 离 & ల్లి- & 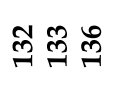 & 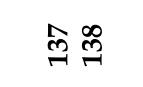 & ले & $\stackrel{9}{9}$ & $\underset{\exists}{ت}$ & Iี \\
\hline & $\begin{array}{l}\mathscr{\Xi}_{0} \\
\text { के }\end{array}$ & 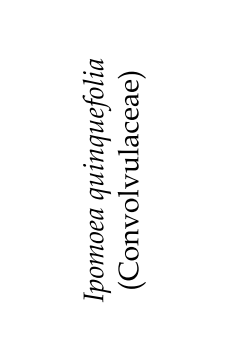 & 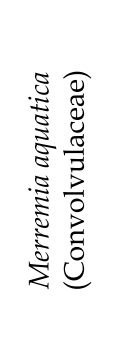 & 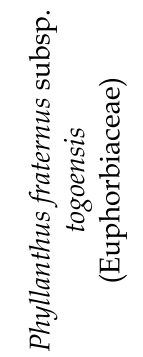 & \multicolumn{4}{|c|}{ 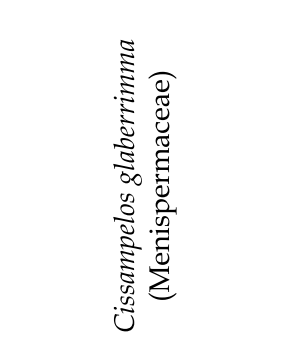 } \\
\hline
\end{tabular}




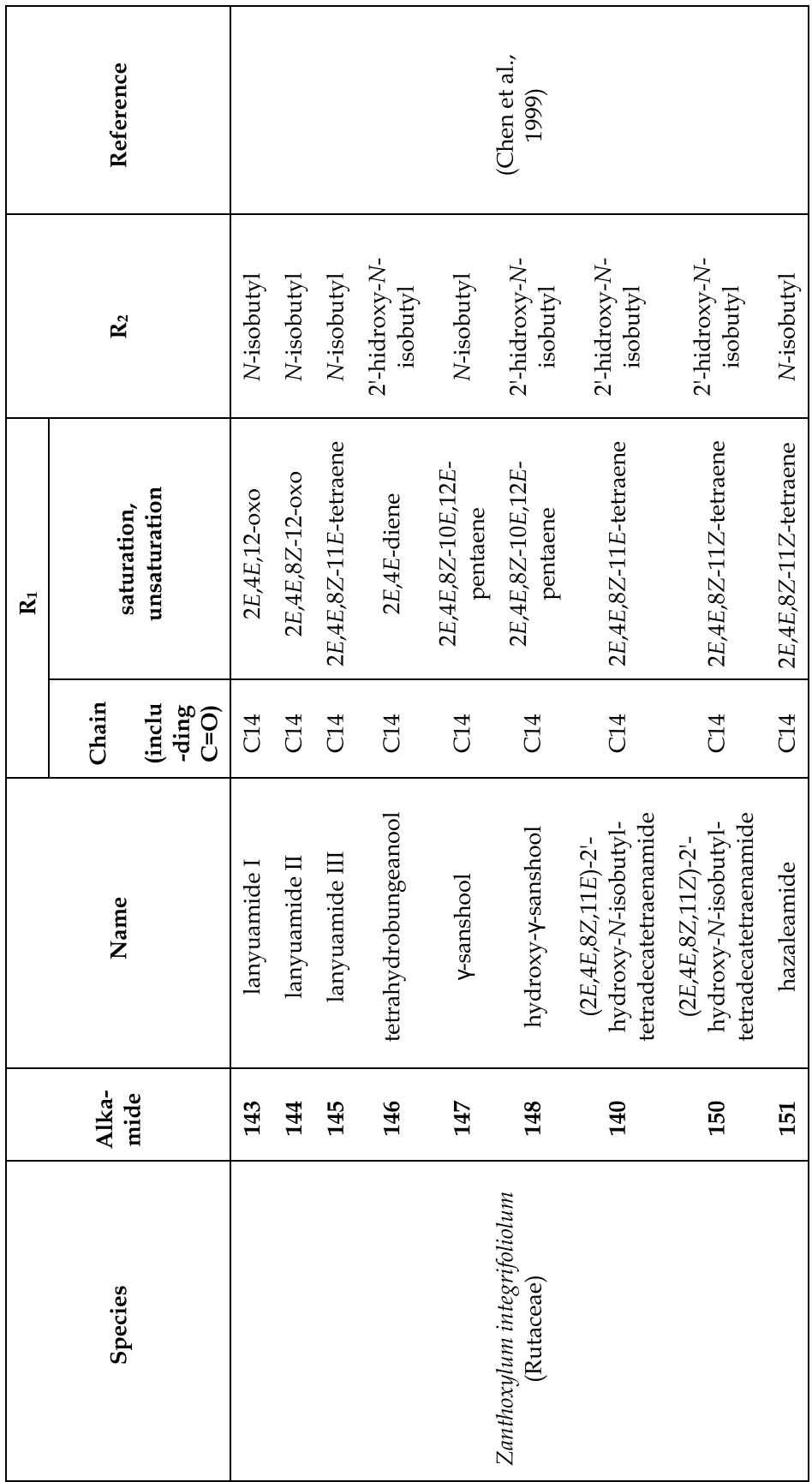

Table 2. Aliphatic alkamides from Convolvulaceae, Euphorbiaceae, Menispermaceae and Rutaceae plant families. 


\subsubsection{Convolvulaceae alkamides}

Convolvulaceae alkamides are also known as alkaloids MQ. These alkamides are characterized by linear or branched saturated acid residues. All Convolvulaceae alkamides have a pyrrolidinyl residue as the amine group and have been isolated from the Ipomoea and Merremia genera (compounds 130-136).

\subsubsection{Euphorbiaceae alkamides}

Phyllanthus fraternus is used by traditional healers and tribes in the northern region of India as a folklore remedy for the treatment of malaria and various liver diseases. An aqueous extract of this plant exhibited antioxidant activity, preventing the oxidation of proteins and lipids. Additionally, aqueous extracts of Phyllanthus fraternus protect against allyl alcoholinduced oxidative stress in liver mitochondria (Sailaja \& Setty, 2006). Two aliphatic alkamides $\mathrm{C}_{4}$ isomers , E,E-2,4-octadienamide (137) and E,Z-2,4-decadienamide (138), have been isolated from this plant. Both isomers lack an alkyl residue at the amine group, which is typically joined to an acid residue (Sittie et al., 1998). Instead, these compounds possess an $\alpha, \beta, \gamma, \delta$-unsaturated conjugated amide, a feature believed to enhance antiplasmodial activity. Notably, in vitro assays of these two isomers demonstrated that these compounds possess moderate antiplasmodial activity.

\subsubsection{Menispermaceae alkamides}

The roots of some species of the Cissampelos genus exhibit significant activity against mechanical, chemical and arthritic pain, increasing the pain threshold and dictating the medicinal value of the plants of this genus. For example, C. glaberrimma is a plant whose bioactivity is a reflection of its alkamide content (alkamides 139-142, Rosario et al., 1996).

\subsubsection{Rutaceae alkamides}

The fruits of Zanthoxylum integrifoliolum possess a pungent taste. Chemical analysis enabled the isolation and identification of nine isobutylamides (143-151). These amides have a $2 E, 4 E-$ dienamide moiety, including an oxo, diene, tetraene or pentaene acidic fragment (table 2). However, no activity has been reported for these molecules.

Amides have also been isolated from the Glycosmis genus (Rutaceae); however, those isolated from this genus are sulfur-containing amides, a rare group of secondary metabolites that have an aromatic amine residue. Glycosmis alkamides will be discussed in section 3.3 (vide infra).

\section{Aromatic alkamides}

Alkamides isolated from Solanaceae, Piperaceae, Brassicaceae and Rutaceae plant families either have one aromatic ring at the amine residue, at the acid residue or both. Capsaicinoids, amides from Lepidium meyenii, and sulfur derivatives from the Glycosmis genus are alkamides with one aromatic ring at the amine residue. Piperine and its analogs are amides with one aromatic residue at the acid fragment. Alkamides that have an aromatic ring at the amine and acid residues are distributed among a large group of plants. 


\subsection{The alkamides from Solanaceae family: Capsaicinoids}

Capsicum (also known as "chile" or "chilli") are species used as vegetables, condiments, and for an important number of medicinal preparations. The fruits of Capsicum have been utilized in food preparation, for medicinal applications to tone body muscles after workouts, hot infusions for toothache and muscle pain and aerosols such as Capsicum extracts that are used as personal protection. This species are the source of highly pungent capsacinoids that induce a hot or burning sensation. Capsaicinoids are the major chemical constituents from the following five domesticated species of Capsicum (peppers) genus: C. annuum L., C. baccatum L., C. chinense Jacq., C. frutescens L. and C. pubescens. All of these species have Nvanillylamides (all contain a 4-hydroxy-3-methoxybenzyl amine group) of C8 to C18 fatty acids (table 3).

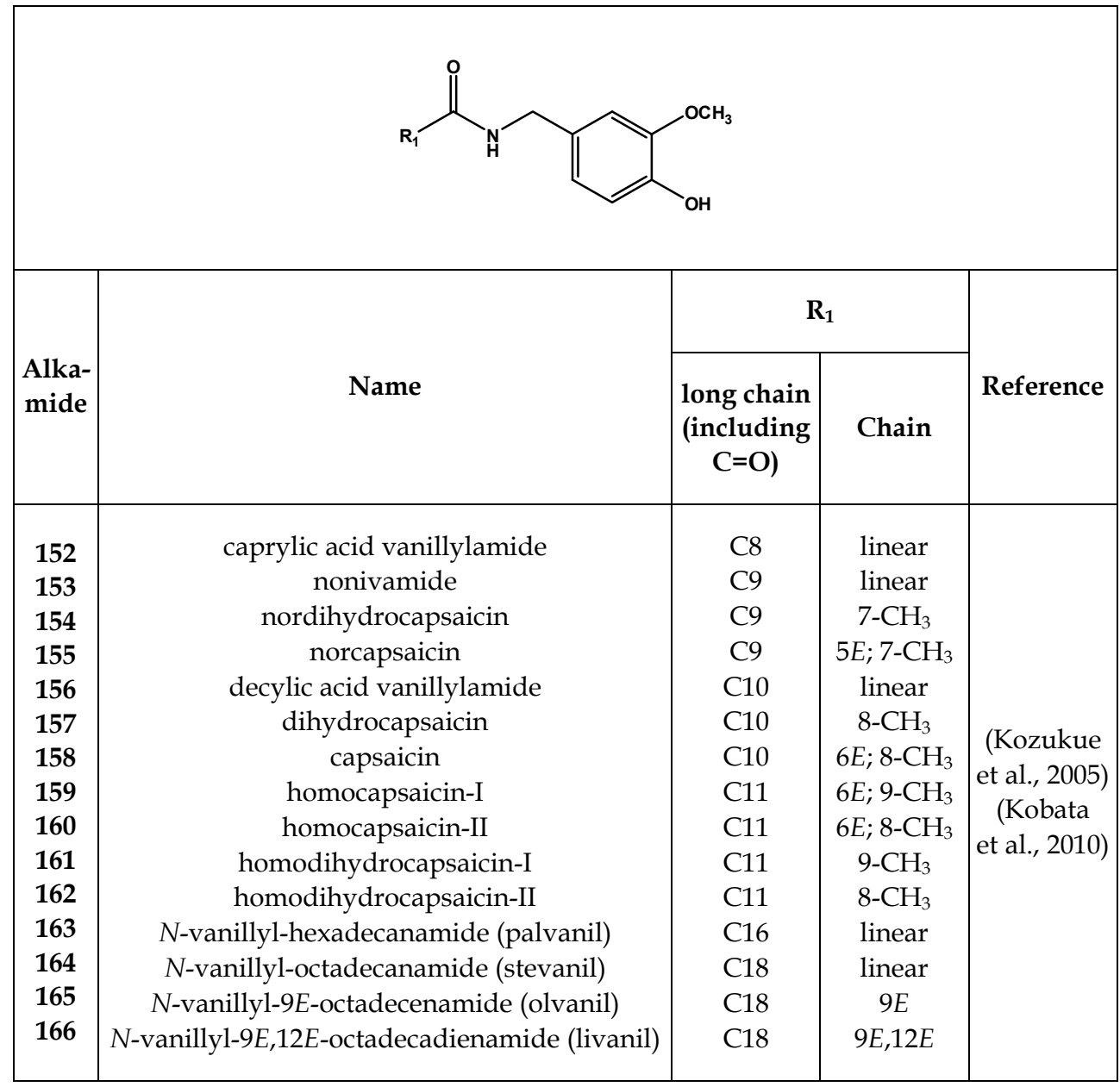

Table 3. Capsaicinoids from Capsicum annuum. 
Some capsaicinoids exhibit strong pungent sensory properties when consumed as part of the diet. Additionally, capsaicinoids possess a variety of biological properties that may affect human health (Kozuke et al., 2010), such as antiviral, antibacterial, antifungal, insecticidal, antioxidative, anti-inflammatory and anticancer activities. Furthermore, capsaicinoids influence neuronal structures that contain substances that are associated with pain transmission and neurogenic inflammation. As a result, these compounds are used as topical analgesics for treating pain. The aforementioned properties are the basis for the use of capsaicinoids to prevent or reduce chronic and age-related pain (Kozuke et al., 2005). Capsaicin (158) and dihydrocapsaicin (157) are notable among natural capsaicinoids because they constitute approximately $90 \%$ of the total capsaicinoids in many varieties of peppers. The burning sensation caused by capsaicin is induced by the direct activation of a nonselective cation channel-transient receptor potential, vanilloid 1 (TRPV1), located at the end of sensory nerves. Several physiological activities caused by capsaicin are related to the activation of the TRPV1 receptor. Meghvansi and coworkers have written a review of capsaicinoids in which their ethnopharmacological applications are discussed (Meghvansi et al., 2010). Long acyl chain capsaicinoids exhibiting similar activities to capsaicin, such as anti-inflammatory, antinociceptive and enhanced adrenaline secretion, have been recently reported. The advantages of these compounds are the lack of irritancy or pungency due to the lower accessibility of TRPV1 in the tongue due to higher lipophilicity compared to capsaicin (Kobata et al., 2010).

\subsection{The alkamides from Lepidium meyenii (Brassicaceae)}

The roots from of L. meyenii are used to enhance fertility and sexual behavior in men and women. Additionally, L. meyenii roots serve as a traditional remedy for menopausal symptoms, the regulation of hormone secretion, immunostimulation, memory improvement, as an antidepressant or anticancer agent, and to prevent anemia. Phytochemical analysis of the roots of this plant led to the identification of $\mathrm{m}$ methoxybenzyl and $\mathrm{N}$-benzyl amine residues and macamides, linear C16, C18 or C24 alkamides with one or two double bonds and possible oxidation of $C_{5}, C_{9}$ or $C_{13}$ (table 4 ).

\subsection{The alkamides from Glycosmis (Rutaceae)}

Sulfur-containing amides (phenethyl/styrylamine-derived amides) form a rare group of secondary metabolites in the Rutaceae family. These amides are only present in the leaves of plants that belong to the Glycosmis genus. Sulfur-containing amides represent a typical chemical profile of this genus. The acid moieties of these alkamides are probably derived from cysteine, which can be oxidized to sulfones and sulfoxides or shortened by $\beta$-oxidation (as in ritigalin). With the exception of simple methylamides, the amine residues are characterized by the presence of phenethyl or styryl groups (derived from phenylalanine) that can be linked to different prenyloxy (dambullins) or geranyloxy groups in para position (gerambullins). More recently, a group of similar (methylsulfonyl)propenoic acid amides has been detected in which dopamine is linked to various oxidized geranyl chains (sakerines). Some of these alkamides exhibit pronounced antifungal and/or insecticidal activity (Greger \& Zechner, 1996) (table 5). 


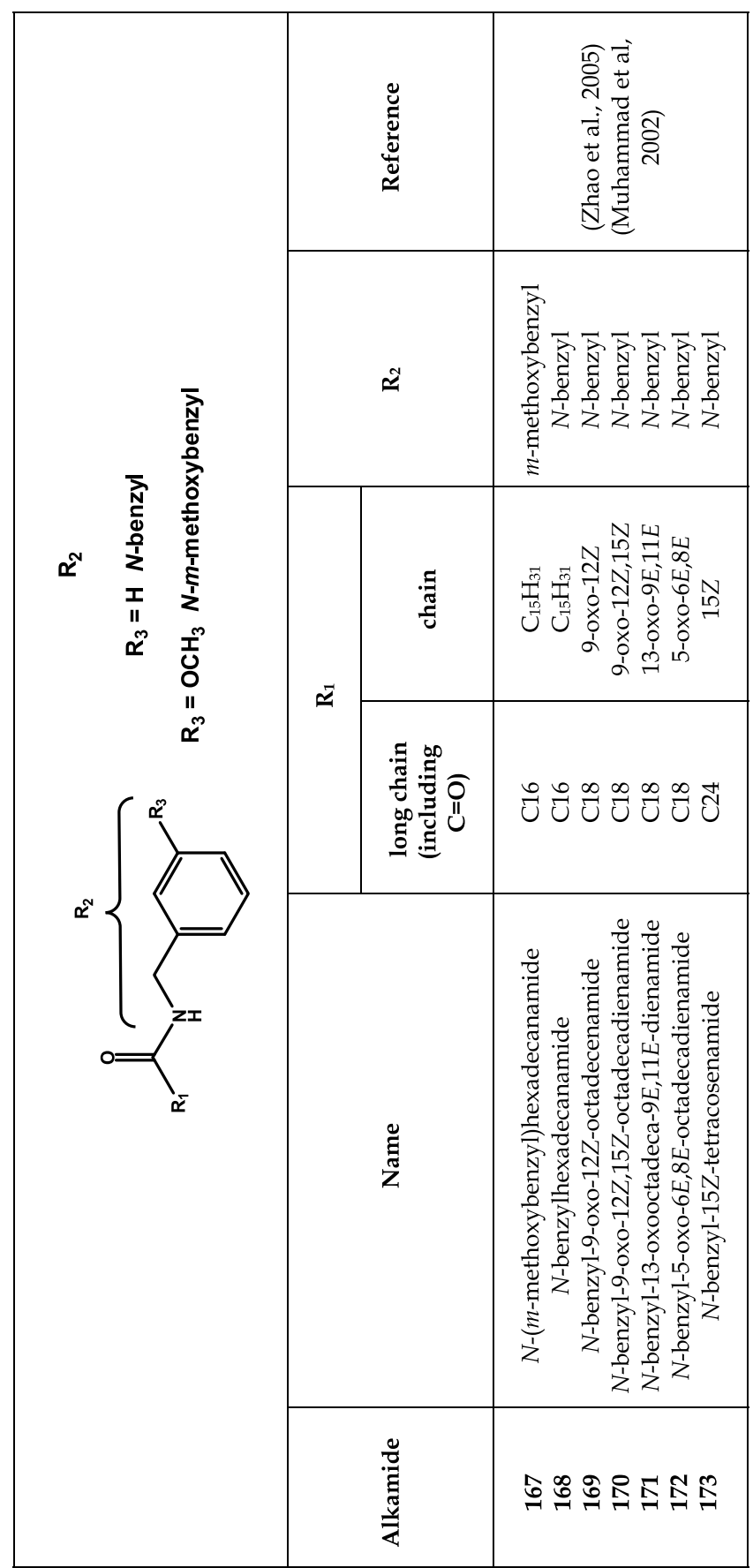

Table 4. Alkamides from Lepidium meyenii. 


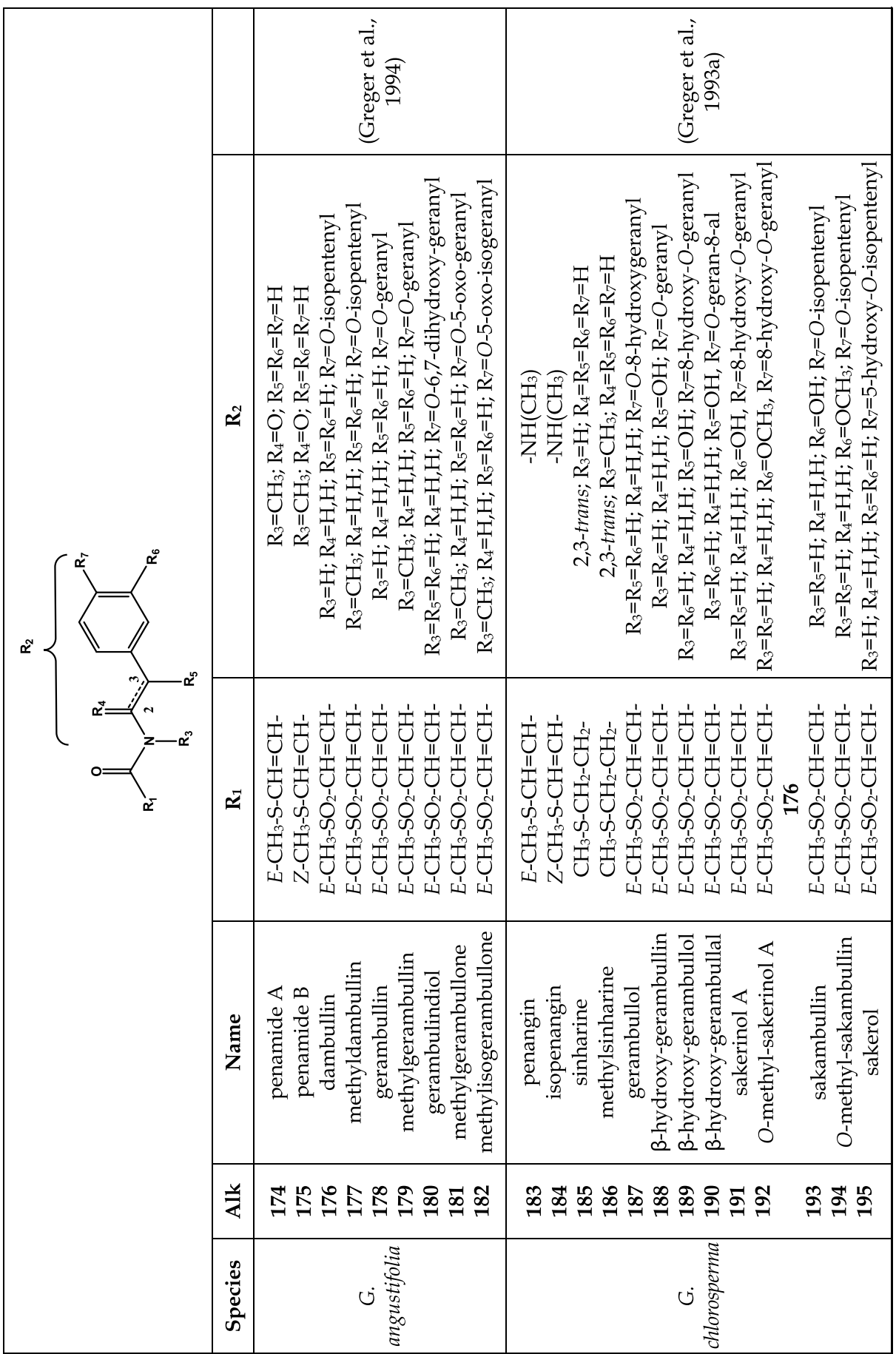




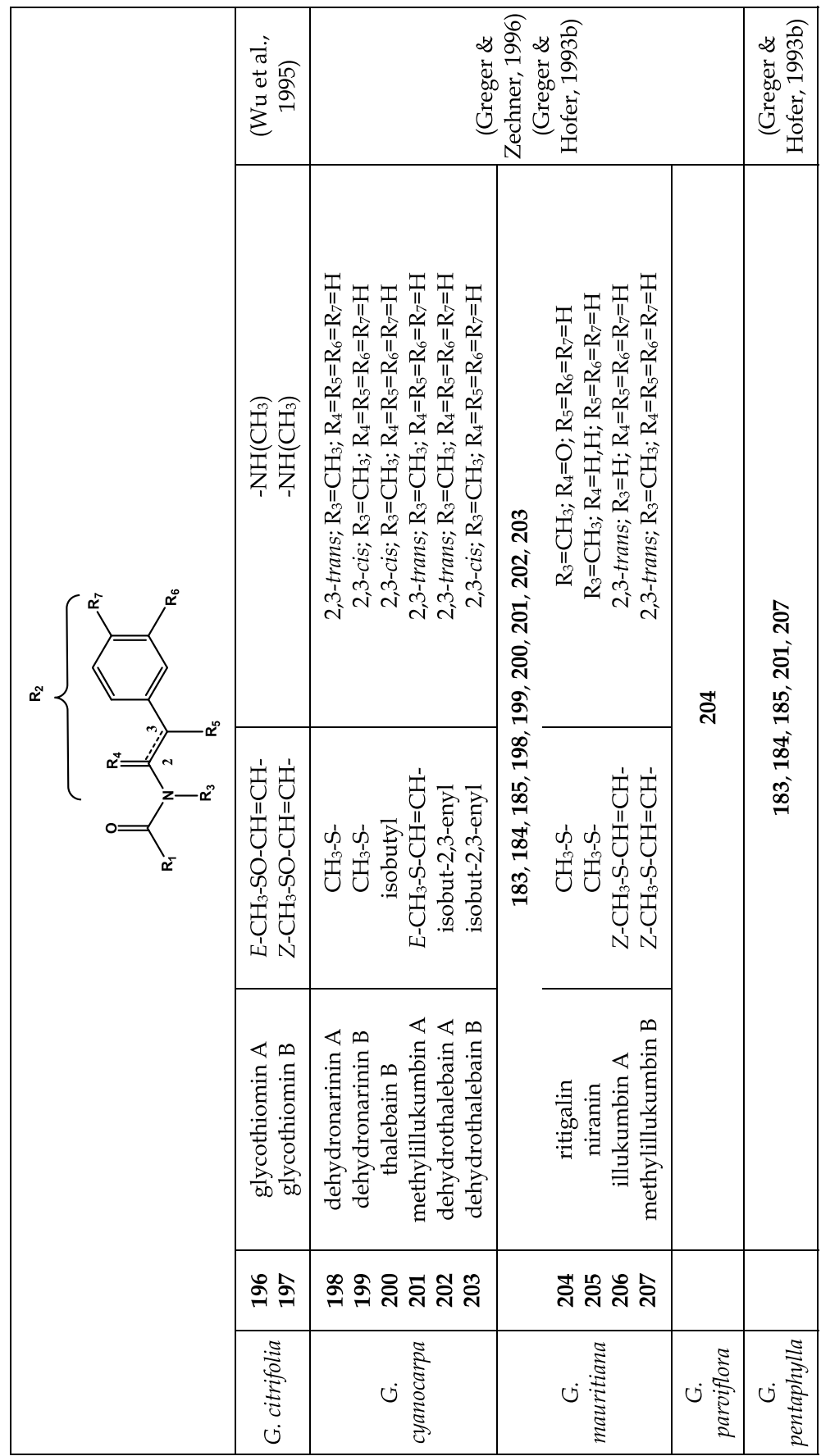

Table 5. Sulfur-containing alkamides from the Glycosmis species. 


\subsection{The Piperaceae family. Piperine and its analogs}

Alkamides from the Piperaceae family are produced by plants that are classified as being in either the Piper, Ottonia or Peperomia genera. These alkamides are characterized by the presence of $N$-isobutyl, N-3-acetoxy-isobutyl, piperidinyl (piperidide), 5,6-dihydro2(1H)pyridinone and pyrrolidinyl groups as amine residues, with $N$-isobutyl and piperidinyl being the most commonly found. The presence of carboxylic acid fragment is also characteristic of the alkamides isolated from plants that belong to the Piperaceae family. These fragments include the $3^{\prime}, 4^{\prime}$-methylenedioxyphenyl as the most common terminal group. However, p-methoxyphenyl, 3',4',5'-trimethoxyphenyl and 4'-hydroxy-3'methoxyphenyl groups can also be joined to a chain of 2, 4, 5, 6, 8, 9, 10, 11, 12 or 14 carbons, with one, two or three unsaturations at the even-numbered carbons (with the exception of $\mathrm{C}_{12}$, fig. 4).

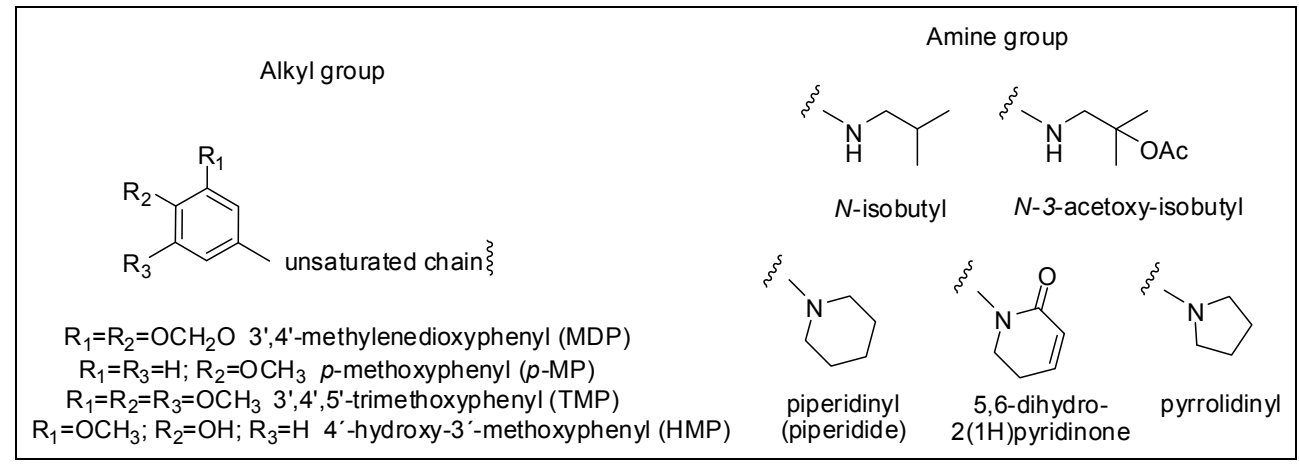

Fig. 4. The most common alkyl and amide residues of alkamides from the Piperaceae family.

Dimeric alkamides have been found in $P$. chaba and $P$. nigrum. $P$. chaba dimers are [4+2] adducts obtained from the combination of piperlonguminine and piperine [chabamide $\mathrm{H}$ (208) and I (209)], two molecules of pellitorine [chabamide J (210), and K (211)], two molecules of piperine [chabamide (212)], or two molecules of piperamine [chabamide F (213) and G (214)] (fig. 5). Notably, these dimeric alkamides exhibited potent cytotoxic activity against the COLO-205 cell line (Rao et al., 2011).

In contrast, $P$. nigrum dimers constituting [2+2] adducts are the combination of either two molecules of piperine [pipercyclobutanamide A (215) and nigramide R (216)] or from the piperine analogue piperrolein A [pipercyclobutanamide C (217)] (Rao et al, 2011; Subehan et al., 2006) (fig. 6).

The compounds produced by the Piperaceae family are pharmacologically very important, as several species of these plants are being used in folkloric medicine in different parts of the world. For example, the roots of plants from the Ottonia genus have a piquant taste and cause intense salivation when are in contact with the mouth. These roots exhibit local anesthetic and hallucinogenic effects and are used in the treatment of toothaches and sore throats. The toothache-relieving reputation of plants that belong to this genus led to the isolation of piperovatine (222), a buccal local anesthesic isobutyl amide isolated from $O$. 
corcovadensis. Alkamides isolated from the Ottonia genus contain 1-oxo-5-( $3^{\prime}, 4^{\prime}-$ methylenedioxyphenyl)-2E,4E-pentadien-1-yl and 1-oxo-6-( $p$-methoxyphenyl)-2E,4Ehexadien-1-yl residues as acidic fragments with $\mathrm{N}$-isobutyl or $\mathrm{N}$-3-acetoxy-isobutyl fragments as the amide residues (Antunes et al., 2001; Costa \& Mors, 1981, table 6).

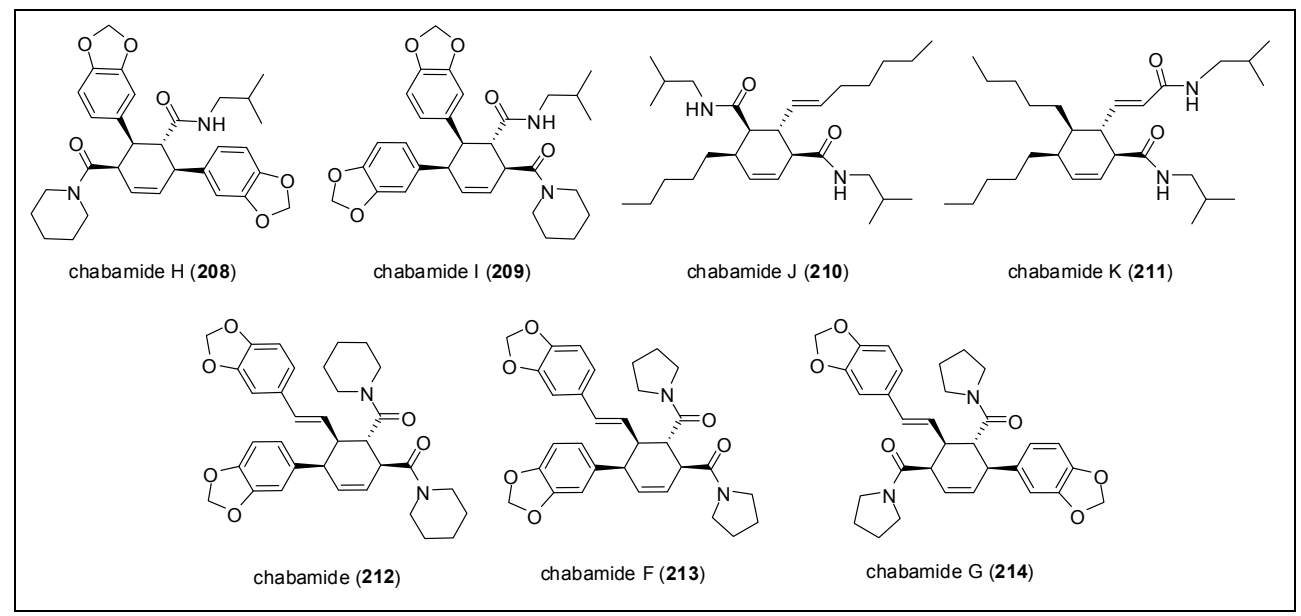

Fig. 5. Dimeric [4+2] alkamides from Piper chaba.

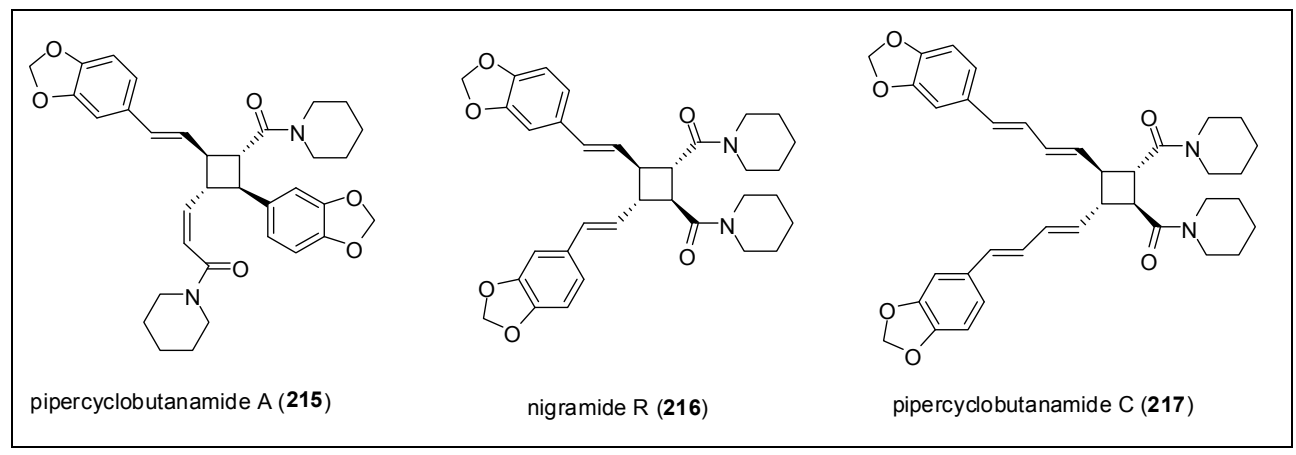

Fig. 6. Dimeric [2+2] alkamides from Piper nigrum.

The Piper species have been used in traditional medicine for thousands of years in China, India and Mexico, among other countries, for the treatment of several diseases and ailments. For example, P. longum is used for treatment of gonorrhea, menstrual and chronic intestinal pain, tuberculosis, sleeping problems, respiratory infections such as coughs, bronchitis and asthma, malarial fever, diarrhea, jaundice and arthritis. The beneficial effects of this species include analgesic and diuretic activities, relaxation of muscle tension, and the alleviation of anxiety. 


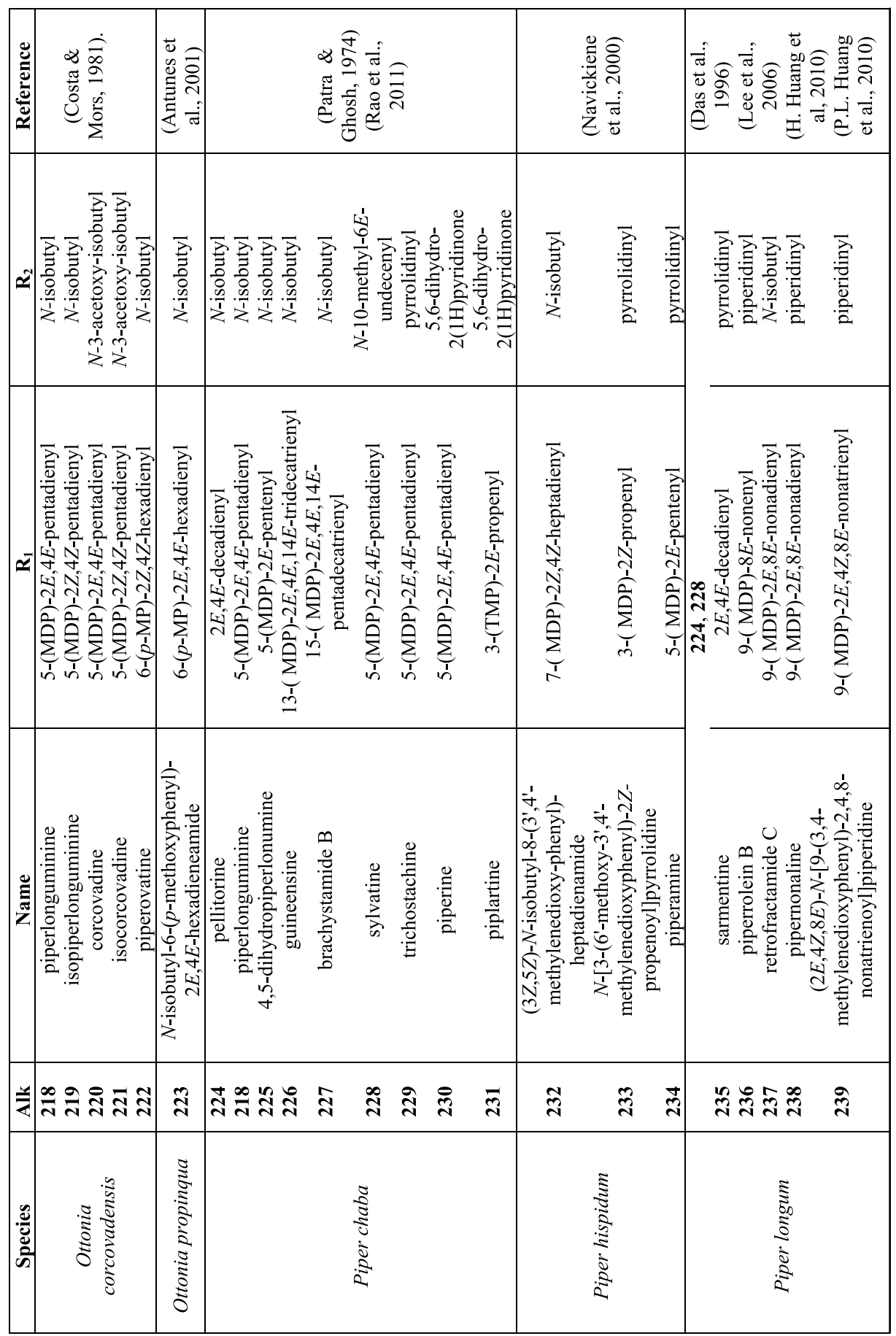




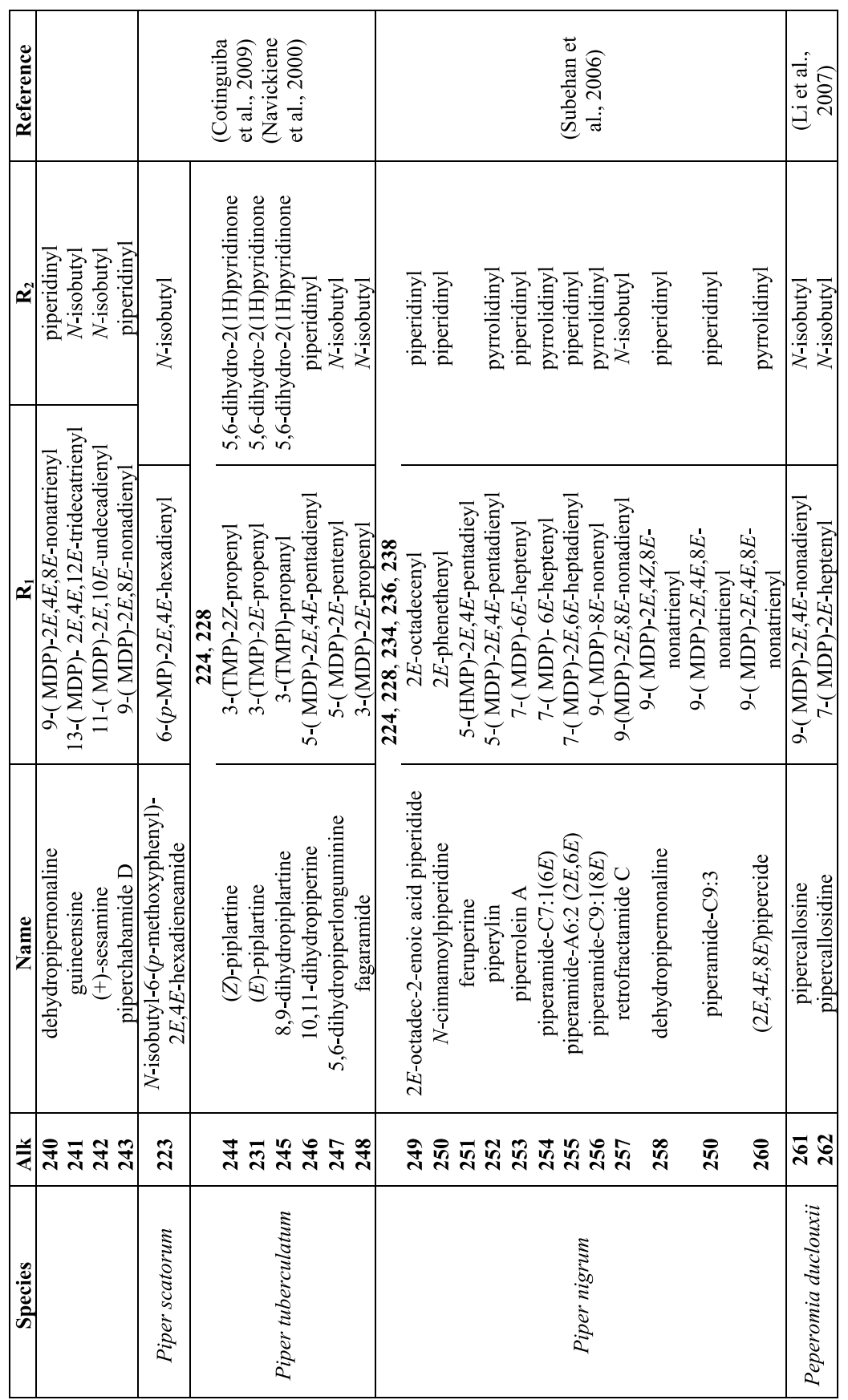

Table 6. Alkamides from the Piperaceae family. $\mathrm{MDP}=3^{\prime}, 4^{\prime}-$ methylenedioxyphenyl; $\mathrm{p}-\mathrm{MP}=p$ methoxyphenyl; TMP= 3',4',5'-trimethoxyphenyl; HMP=4'-hydroxy-3'-methoxyphenyl. 
In contrast, $P$. hispidum and $P$. tuberculatum exhibit antifungal activity and produce amides with the cis geometry in their side chains, a structural feature quite rare in nature (table 6, Navickiene et al., 2000).

Pipernonaline (238) is an alkamide possessing mosquito larvicidal activity that has been isolated from P. longum (Huang et al., 2010), whereas some piperamides, such as (Z)piplartine (244), (E)-piplartine (231), 8,9-dihydropiplartine (245) and pellitorine (228), isolated from P. tuberculatum seeds have been shown to inhibit the proliferation of Trypanosoma cruzi parasites. These alkamides are considered to be templates for the design of novel and potent hit compounds for the treatment of Chagas' disease (Cotinguiba et al., 2009).

Piperine ( $E, E$ isomer of 1-piperolypiperidine, 224) is the major component in the fruits of several species of Piper, particularly P. longum and P. nigrum. This compound showed diverse biological activities such as antioxidant, anti-inflammatory, analgesic, antiplatelet aggregation, antihyperlipidemic, antihypertensive, cytoprotective, antitumor, antimicrobial, hepatoprotective and antidepressant activities. The structure of piperine resembles that of Capsaicin (158, table 3), the pungent component in the majority of the chilli peppers species. Similar to capsaicin, piperine also serves as a natural agonist of the vanilloid receptor (TRPV1 channel), which is involved in the neurotransmission of thermal and nociceptive stimuli.

Piplartine (5,6-dihydro-1-[(2E)-1-oxo3-(3', 4', 5'-trimethoxyphenyl)-2-propen-1-yl]-2(1H)pyridinone, 244, table 6) is another important alkamide isolated from the Piper species. This compound exhibits antifungal properties and has demonstrated antiplatelet aggregation, anxiolytic, antidepressant and antitumor activities in murine models. This naturally occurring alkamide is also a cytotoxic agent against cultured tumor cells, exhibiting promising anticancer properties. However, piplartine also shows mutagenic activity in yeast and cultured mammalian cells, inducing in vitro and in vivo chromosomal damage, potentially due to DNA breaks (Bezerra et al., 2009). The alkamides isolated from plants that belong to the Piper family are shown in table 6 .

\section{Other family plants - Alkamides with both fragments including aromatic residues}

The cinnamoylbenzylamide tribulusimide (263, fig. 7) and several cinnamoylphenethylamides (table 7) and benzylphenethylamides (table 8) are the condensation products of cinnamic acid and benzylamine derivatives, cinnamic acid and phenethylamine and benzylic acid and phenethylamine, respectively. These alkamides have been isolated from a broad variety of plants that belong to at least 28 families. A selection of these alkamides are shown in table 9 .<smiles>O=C(/C=C/c1ccc(O)cc1)NC(=O)c1ccc(O)cc1</smiles>

Fig. 7. Cinnamoylbenzylamide. 


\begin{tabular}{|c|c|c|c|c|c|c|c|}
\hline Alkamide & Name & $\mathbf{R}_{1}$ & $\mathbf{R}_{2}$ & $\mathbf{R}_{3}$ & $\mathbf{R}_{4}$ & $\mathbf{R}_{5}$ & $\mathbf{R}_{6}$ \\
\hline 264 & $p$-coumaroyltyramine & $\mathrm{H}$ & $\mathrm{OH}$ & $\mathrm{H}$ & $\mathrm{H}$ & $\mathrm{H}$ & $\mathrm{OH}$ \\
\hline 265 & caffeoyltyramine & $\mathrm{OH}$ & $\mathrm{OH}$ & $\mathrm{H}$ & $\mathrm{H}$ & $\mathrm{H}$ & $\mathrm{OH}$ \\
\hline 266 & feruloyltyramine & $\mathrm{OCH}_{3}$ & $\mathrm{OH}$ & $\mathrm{H}$ & $\mathrm{H}$ & $\mathrm{H}$ & $\mathrm{OH}$ \\
\hline 267 & dihydro-feruloyltyramine & $\mathrm{OCH}_{3}$ & $\mathrm{OH}$ & $\mathrm{H}$ & $\mathrm{H}$ & $\mathrm{H}$ & $\mathrm{OH}$ \\
\hline 268 & sinapoyltyramine & $\mathrm{OCH}_{3}$ & $\mathrm{OH}$ & $\mathrm{OCH}_{3}$ & $\mathrm{H}$ & $\mathrm{H}$ & $\mathrm{OH}$ \\
\hline 269 & feruloylmethoxytyramine & $\mathrm{OCH}_{3}$ & $\mathrm{OH}$ & $\mathrm{H}$ & $\mathrm{H}$ & $\mathrm{OCH}_{3}$ & $\mathrm{OH}$ \\
\hline 270 & terrestriamide & $\mathrm{OCH}_{3}$ & $\mathrm{OH}$ & $\mathrm{H}$ & $=\mathrm{O}$ & $\mathrm{H}$ & $\mathrm{OH}$ \\
\hline 271 & feruloyldopamine & $\mathrm{OCH}_{3}$ & $\mathrm{OH}$ & $\mathrm{H}$ & $\mathrm{H}$ & $\mathrm{OH}$ & $\mathrm{OH}$ \\
\hline 272 & coumaroyldopamine & $\mathrm{H}$ & $\mathrm{OH}$ & $\mathrm{H}$ & $\mathrm{H}$ & $\mathrm{OH}$ & $\mathrm{OH}$ \\
\hline 273 & feruloyl-4-O-methyldopamine & $\mathrm{OCH}_{3}$ & $\mathrm{OH}$ & $\mathrm{H}$ & $\mathrm{H}$ & $\mathrm{OH}$ & $\mathrm{OCH}_{3}$ \\
\hline 274 & feruloyl-3-O-methyldopamine & $\mathrm{OCH}_{3}$ & $\mathrm{OH}$ & $\mathrm{H}$ & $\mathrm{H}$ & $\mathrm{OCH}_{3}$ & $\mathrm{OH}$ \\
\hline 275 & $p$-coumaroyl-3-O-methyldopamine & $\mathrm{H}$ & $\mathrm{OH}$ & $\mathrm{H}$ & $\mathrm{H}$ & $\mathrm{OCH}_{3}$ & $\mathrm{OH}$ \\
\hline 276 & $\begin{array}{l}\text { 2-(4'-hydroxyphenyl) } \\
\text { ethylcaffeic amide }\end{array}$ & $\mathrm{OH}$ & $\mathrm{OH}$ & $\mathrm{H}$ & $\mathrm{H}$ & $\mathrm{H}$ & $\mathrm{OH}$ \\
\hline 277 & $N$-cis-feruloyloctopamine & $\mathrm{OCH}_{3}$ & $\mathrm{OH}$ & $\mathrm{H}$ & $\mathrm{OH}$ & $\mathrm{H}$ & $\mathrm{OH}$ \\
\hline 278 & coumaroyloctopamine & $\mathrm{H}$ & $\mathrm{OH}$ & $\mathrm{H}$ & $\mathrm{OH}$ & $\mathrm{H}$ & $\mathrm{OH}$ \\
\hline 279 & $\begin{array}{c}\beta \text {-( } p \text {-hydroxy-phenylethyl }) \\
p \text {-hydroxycinnamamide }\end{array}$ & $\mathrm{H}$ & $\mathrm{OH}$ & $\mathrm{H}$ & $\mathrm{H}$ & $\mathrm{H}$ & $\mathrm{OH}$ \\
\hline 280 & 3-methoxyaegeline & $\mathrm{H}$ & $\mathrm{H}$ & $\mathrm{H}$ & $\mathrm{OH}$ & $\mathrm{OCH}_{3}$ & $\mathrm{OCH}_{3}$ \\
\hline 281 & 3-methoxy-7-acetylaegeline & $\mathrm{H}$ & $\mathrm{H}$ & $\mathrm{H}$ & OAc & $\mathrm{OCH}_{3}$ & $\mathrm{OCH}_{3}$ \\
\hline 282 & 3-methoxy-7-cinnamoylaegeline & $\mathrm{H}$ & $\mathrm{H}$ & $\mathrm{H}$ & Ocinnamoyl & $\mathrm{OCH}_{3}$ & $\mathrm{OCH}_{3}$ \\
\hline
\end{tabular}

Table 7. Cinnamoylphenethylamides isolated from diverse plants.

\begin{tabular}{|c|c|ccc|}
\hline \multicolumn{2}{|c|}{} & & & \\
\hline
\end{tabular}

Table 8. Benzylphenethylamides isolated from diverse plants.

Despite the broad distribution of alkamides with both fragments, including aromatic residues among a wide variety of plant families, the presence of feruloyltyramine (266) is exceptionally important because it is a common compound found in the majority of alkamide-producing plants. The $Z$ - and E-stereoisomers of feruloyltyramine have been isolated and are two of the most frequently characterized alkamides. The second most important alkamide is p-coumaroyltyramine (264), which is isolated also in both stereoisomeric forms, the E-stereoisomer being the most common (table 9). 


\begin{tabular}{|c|c|c|c|c|}
\hline Family & \multicolumn{2}{|c|}{ Species } & Alkamide & Reference \\
\hline Alliaceae & \multicolumn{2}{|c|}{ Allium fistulosum } & 264 & (Nishioka et al., 1997) \\
\hline \multirow{3}{*}{ Amaranthaceae } & & hypochondriacus & $264,265,266,268,271,273$ & \multirow{2}{*}{ (Pedersen et al., 2010) } \\
\hline & & mantegazzianus & $264,265,266,268,271,273$ & \\
\hline & \multicolumn{2}{|c|}{ Achyranthes ferruginea } & trans-273 & (Alam et al, 2003) \\
\hline Anacardiaceae & \multicolumn{2}{|c|}{ Mangifera indica } & 276 & $\begin{array}{c}\text { (Ghosal \& Chakrabarti, } \\
1988 \text { ) } \\
\end{array}$ \\
\hline Annonaceae & \multicolumn{2}{|c|}{ Annona cherimola } & $\begin{array}{l}\text { 264, cis-265, cis-266, 267, } \\
\text { cis-269, trans-269 }\end{array}$ & (Chen et al., 1998) \\
\hline \multirow[t]{2}{*}{ Aristolochiaceae } & \multirow[t]{2}{*}{ Aristolochia } & gehrtii & 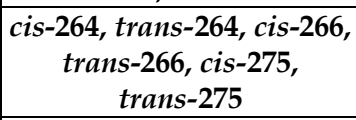 & $\begin{array}{l}\text { (Navickiene \& Lopes, } \\
\text { 2001) }\end{array}$ \\
\hline & & gigantea & $\begin{array}{c}\text { trans-264, trans-266, cis- } \\
275,276, \text { cis-277 } \\
\end{array}$ & $\begin{array}{c}\text { (Holzbach \& Lopes, } \\
\text { 2010) }\end{array}$ \\
\hline Cannabidaceae & \multicolumn{2}{|c|}{ Cannabis sativa } & 264, trans -265, trans -266 & (Sakakibara et al, 1991) \\
\hline Chenopodiaceae & \multicolumn{2}{|c|}{ Chenopodium album } & trans-273, cis-275 & (Horio et al., 1993) \\
\hline Concolvulaceae & \multicolumn{2}{|c|}{ Ipomoea aquatica } & cis-266, trans-266 & (Tseng et al., 1992) \\
\hline Euphobiaceae & \multicolumn{2}{|c|}{ Antidesma membranaceum } & $\begin{array}{c}\text { trans-266, cis-277, } \\
\text { trans-277 }\end{array}$ & (Buske et al., 1997) \\
\hline Flacourtiaceae & \multicolumn{2}{|c|}{ Casearia membranacea } & cis-266, trans-266 & (Chang et al., 2003) \\
\hline Fumariaceae & \multicolumn{2}{|c|}{ Dactylicapnos torulosa } & trans-266 & (Rucker et al., 1994) \\
\hline Hernandiaceae & \multicolumn{2}{|c|}{$\begin{array}{l}\text { Sparattanthelium } \\
\text { tupiniquinorum }\end{array}$} & trans-264, trans-266 & (Pereira et al., 2007) \\
\hline Laur & \multicolumn{2}{|c|}{ Actinodaphne longifolia } & trans-266, trans-273 & (Tanaka et al., 1989) \\
\hline Leguminosae & \multicolumn{2}{|c|}{ Mucuna birdwoodiana } & trans -266 & (Goda et al., 1987) \\
\hline Magnoliaceae & \multicolumn{2}{|c|}{ Michelia alba } & cis-266, trans-266 & (Chen et al., 2008) \\
\hline Malvaceae & \multicolumn{2}{|c|}{ Hibiscus taiwanensis } & cis-266, trans-266 & (Wu et al., 2005) \\
\hline Menispermaceae & \multicolumn{2}{|c|}{ Sinomenium acutum } & 266 & (Otsuka et al., 1993) \\
\hline Nyctagenaceae & \multicolumn{2}{|c|}{ Mirabilis jalapa } & trans-273 & (Michalet et al., 2007) \\
\hline \multirow{2}{*}{ Papaveraceae } & \multirow{2}{*}{ Hypecoum } & imberbe & trans-266 & \multirow{2}{*}{ (Hussain et al., 1982) } \\
\hline & & parviflorum & trans-266 & \\
\hline Piper & \multicolumn{2}{|c|}{ Peperomia duclouxii } & $\begin{array}{l}268, \text { trans-274, } \\
\text { trans-271, } 283\end{array}$ & (Li et al., 2007) \\
\hline Plumbaginaceae & \multicolumn{2}{|c|}{ Ceratostigma willmottianum } & trans-265, trans-266 & (Yue et al., 1997) \\
\hline Polygonaceae & \multicolumn{2}{|c|}{ Eskemukerjea megacarpum } & trans-266 & (Miyaichi et al., 2006) \\
\hline Portulacaceae & \multicolumn{2}{|c|}{ Portulaca oleracea } & trans-266 & (Mizutani et al., 1998) \\
\hline & Evod & dia belahe & 279 & (Pedersen et al. , 2010) \\
\hline Rutaceae & Pleiospern & mium alatum & 284,285 & (Chatterjee et al., 1975) \\
\hline & Zanthoxyl & um syncarpum & $280,281,282$ & (Ross et al., 2005) \\
\hline & Solanum & khasianum & $\begin{array}{c}\text { cis-264, trans-264, cis-266, } \\
\text { trans-266, cis-277, } \text { trans- } \\
277, \text { cis-278, trans-278 }\end{array}$ & $\begin{array}{c}\text { (Muhlenbeck et al., } \\
\text { 1996) }\end{array}$ \\
\hline Solanaceae & & lycopersicum & $264,266,272,273$ & (Zacares et al., 2007) \\
\hline & & citrullifolium & trans-266 & \\
\hline & Cestru & m lanatum & trans-266 & \\
\hline Zygophyllaceae & Tribulu & us terrestris & 24, trans $-265,271,263$ & (Lv et al., 2008) \\
\hline
\end{tabular}

Table 9. Distribution of alkamides including both acid and amide residues. 
These alkamides have been associated with diverse biological activities, such as the potentiation of antibiotics, inhibition of prostaglandin biosynthesis, antioxidant activity and more. Furthermore, cinnamoylphenethylamines have been suggested to have an impact on human health if present in the diet (Pedersen et al., 2010).

Some dimeric alkamides have been isolated from Cannabis sativa (Cannabinaceae, Sakakibara et al., 1991) (fig. 8).

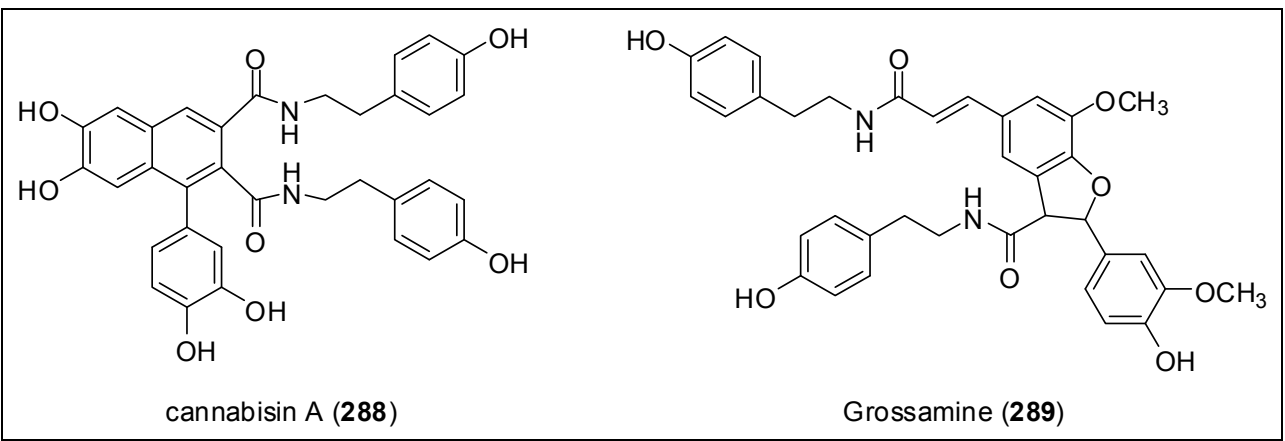

Fig. 8. Dimeric alkamides from Cannabis sativa.

\section{Conclusion}

Alkamides are natural products distributed among several medicinal plants that are a part of at least 33 families. These plants are used for a variety of medicinal purposes in many places throughout the world. Chemical and pharmacological research of these plants have established that alkamides contribute to the notable bioactivity of these plants. Asteraceae, Solanaceae, Rutaceae and Piperaceae are plant families that specialize in the biosynthesis of these natural products. Importantly, alkamides are chemical markers for plants in each family and genus.

Alkamides with both acid and amine aliphatic residues are characteristic compounds produced by the Asteraceae family, especially from the Achillea, Acmella, Spilanthes, Echinaceae and Heliopsis genera. Alkamides with one aromatic residue can be classified in the following two groups: (1) alkamides with an aromatic residue at the amine core and (2) alkamides with an aromatic residue at the acid. The first group has been isolated from the Solanaceae family, specifically from the Capsicum genus for which those alkamides are named "capsaicinoids". Other alkamides that belong to this group have been isolated from the Lepidium (Brassicaceae) and Glycosmis (Rutaceae) genera. Glycosmis alkamides are rare and have characteristic sulfur-containing structures. The second group corresponds to piperine and its analogs. These compounds are characteristic of the Piper genus (Piperaceae). Furthermore, the alkamides with both acid and amine aromatic residues are widely distributed among at least 28 plant families. Feruloyltyramine and $p$-coumaroyltyramine are the most commonly isolated alkamides that belong to this group of compounds.

Pure alkamides and plants that produce alkamides have a pungent and/or irritating taste as well as analgesic and anesthetic effects. Many alkamides are used to treat dental, muscular 
and arthritic pain. Some alkamides are also consumed to enhance immune response and to relieve colds, respiratory infections and influenza. Anti-inflammatory activity is associated with all of these natural products. Despite the relatively simple structures of alkamides, these compounds have attracted several research groups to study their diversity, distribution and chemical and pharmacological behaviours. Additionally, alkamides have been observed to exhibit many other bioactivities, making these compounds a relatively new and promising family of natural products.

\section{Acknowledgments}

To CONACyT (Grant number 79584-Q). I am grateful to Enrique Salazar Leyva for technical assistance. I apologize to all colleagues whose studies were not cited due to space limitations.

\section{References}

Acosta-Madrid, I.I.; Castañeda-Hernández, G.; Cilia-López, V.G.; Cariño-Cortés, R.; PérezHernández, N. Fernández-Martínez, E. \& Ortiz, M.I. (2009). Interaction between Heliopsis longipes extract and diclofenac on the thermal hyperalgesia test. Phytomedicine, Vol.16, No.4, (April 2009), pp. 336-341, doi:10.1016/j.phymed.2008.12.014

Alam, A.H.M.K.; Sadik, G.; Harun, O.R.; Hasan, C.M. \& Rashid, M.A. (2003). N-transferuloyl-4-methyldopamine from Achyranthes ferruginea. Biochemical Systematics and Ecology, Vol.31, No.11, (November 2003), pp. 1345-1346, doi:10.1016/S03051978(03)00115-7

Antunes, P.A.; Chierice, G.O.; Constantino, C.J.L. \& Aroca, R.F. (2001). Spectroscopic characterization of $N$-isobutyl-6-p-methoxyphenyl) 2E,4E-hexadieneamide extracted from Ottonia propinqua. Vibrational Spectroscopy, Vol.27, No.2, (December 1989), pp. 175-181, doi:10.1016/S0924-2031(01)00132-1

Bauer, R. \& Remiger, P. (1989a). TLC and HPLC analysis of alkamides in Echinaceae drugs. Planta Medica, Vol.55, No.4, (January 1989), pp. 367-371, doi:10.1055/s-2006-962030

Bauer, R.; Remiger, P. \& Wagner, H. (1989b). Alkamides from the roots of Echinaceae angustifolia. Phytochemistry, Vol.28, No.2, (September 1989), pp. 505-508, doi:10.1016/0031-9422(89)80042-1

Bauer, R. \& Foster, S. (1991). Analysis of alkamides and caffeic acid derivatives from Echinaceae simulata and Echinaceae paradoxa roots. Planta Medica, Vol.57, No.5, (October 1991), pp. 447-449, doi:10.1055/s-2006-960147

Bauer, R.; Reming, P. \& Alstat, E. (1990). Alkamides and caffeic acid derivatives from the roots of Echinaceae tennesseensis. Planta Medica, Vol.67, No.6, (December 1990), pp. 533-534

Bezerra, D.P.;Vasconcellos, M.C.; Machado, M.S.; Villela, I.V.; Rosa, R.M.; Moura, D.J.; Pessoa, C.; Moraes, M.O.; Silveira, E.R.; Lima M.A.S.; Aquino, N.C.; Henriques, J.A.P.; Saffi, J. \& Costa-Lotufo, L.V. (2009). Piplartine induces genotoxicity in eukaryotic but not in prokaryotic model systems. Mutation Research, Vol.677, No.12, (June-July 2009), pp. 8-13, doi: 10.1016/j.mrgentox.2009.04.007 
Binns, S.E.; Hudson, J. ; Merali, S. \& Arnason, J.T. (2002). Antiviral activity of characterized extracts from Echinaceae spp. (Heliantheae : Asteraceae) against Herpes simplex virus (HSV-1). Planta Medica, Vol 68, No.9, (September 2002), pp. 780-783, doi:10.1055/s2002-34397

Bohlmann, F.; Ziesche, J.; Robinson, H. \& King, M.R. (1980). Neue amide aus Spilanthes alba. Phytochemistry, Vol.19, No.7, (July 1980), pp. 1535-1537, doi: 10.1016/00319422(80)80212-3

Bohlmann, F.; Hartono, L. \& Jakupovic, J. (1985). Highly unsaturated amides from Salmea scandens. Phytochemistry, Vol.24, No.3, (March 1985), pp. 595-596, doi: 10.1016/S0031-9422(00)80774-8

Booonen, J.; Baert, L.; Burvenich, C.; Blondeelc, P.; De Saegerd, S. \& De Spiegeleera B. (2010). LC-MS profiling of $\mathrm{N}$-alkylamides in Spilanthes acmella extract and the transmucosal behaviour of its main bioactive spilanthol. Journal of Pharmaceutical and Biomedical Analysis, Vol.53, No.3, (November 2010), pp. 243-249, doi:10.1016/j.jpba.2010.02.010

Buske, A.; Schmidt, J.; Porzel, A. \& Adam, G. (1997). Benzopyranones and ferulic acid derivatives from Antidesma membranaceum. Phytochemistry, Vol.46, No.8, (December 1997), pp. 1385-1388, doi:10.1016/S0031-9422(97)00488-3

Calle, J.; Rivera, A. ; Reguero, M.T. ; del Rio, R.E. \& Joseph-Nathan, P. (1988). Estudio del espilantol usando técnicas de resonancia magnética nuclear en dos dimensiones. Revista Latinoamericana de Quimica, Vol.19, pp. 94-97

Campos-Cuevas, J.C; Pelagio-Flores, R.; Raya-Gonzalez, J.; Mendez-Bravo, A.; Ortiz-Castro, R. \& Lopez-Bucio, J. (2008). Tissue culture of Arabidopsis thaliana explants reveals a stimulatory effect of alkamides on adventitious root formation and nitric oxide accumulation. Plant Science, Vol.174, No.2, (February 2008), pp. 165-173, doi:10.1016/j.plantsci.2007.11.003

Cariño-Cortés, R.; Gayosso-De-Lucio, J.A.; Ortiz, M.I.; Sánchez-Gutiérrez, M.; García-Reyna, P.B.; Cilia-López, V.G.; Pérez-Hernández, N.; Moreno, E. \& Ponce-Monter H. (2010). Antinociceptive, genotoxic and histopathological study of Heliopsis longipes S.F. Blake in mice. Journal of Ethnopharmacology, Vol.130, No.2, (July 2010), pp. 216221, doi:10.1016/j.jep.2010.04.037

Casado, M.; Ortega, M.G. ; Peralta, M.; Agnese, A.M. \& Cabrera, J.L. (2009). Two new alkamides from roots of Acmella decumbens. Natural Product Research, Vol.23, No.14, (September 2009), pp. 1298-1303, doi:10.1080/14786410802518201

Cech, N.B.; Tutor, K.; Doty, B.A.; Spelman, K.; Sasagawa, M.; Raner, G.M. \& Wenner, C.A. (2006). Liver enzyme-mediated oxidation of Echinacea purpurea alkylamides: Production of novel metabolites and changes in immunomodulatory activity. Planta Medica, Vol.72, No.15, (December 2006), pp. 1372-1377, doi:10.1055/s-2006951718

Chang, K.C.; Duh, C.Y.; Chen, I.S. \& Tsai, I.L. (2003). A cytotoxic butenolide, two new dolabellane diterpenoids, a chroman and a benzoquinol derivative Formosan Casearia membranacea. Planta Medica, Vol.69, No.7, (July 2003), pp. 667-672, doi:10.1055/s-2003-41120

Chatterjee, A.; Chakrabarty, M. \& Kundu, A.B. (1975). Constituenys of Pleiospermium alatum: alatamide and N-benzoyltyramine methyl ether. Australian Journal Chemistry, Vol.28, No.2, (March 1975), pp. 457-460, doi:10.1071/CH9750457 
Chen, C.Y.; Chang, F.R.; Yen, H.F. \& Wu, Y.C. (1998). Amides from stems of Annona cherimola. Phytochemistry, Vol.49, No.5, (November 1998), pp. 1443-1447, doi:10.1016/S0031-9422(98)00123-X

Chen, I.-S.; Chen, T.-L.;Lin, W.-Y.; Tsai, I.-L. \& Chen, Y.-Ch.(1999). Amides from stems of Isobutylamides from the fruit of Zanthoxylum integrifoliolum. Phytochemistry, Vol.52, No.2, (September 1999), pp. 357-360, doi: 10.1016/S0031-9422(99)00175-2

Chen, C.Y.; Huang, L.Y.; Chen, L.J.; Lo, W.L.; Kuo, S.Y.; Wang, Y.D.; Kuo, S.H. \& Hsieh, T.J. (2008). Chemical constituents from the leaves of Michelia alba. Chemistry of Natural Compounds, Vol.44, No.1, (January 2008), pp. 137-139, doi: 10.1007/s10600-0080043-7

Chen, Y.; Fu, T.; Tao, T.; Yang, J.; Chang, Y.; Wang, M.; Kim, L.; Qu, L.; Cassdy, J.; Scalzo, R. \& Wang, X. (2005). Macrophage Activating Effects of New Alkamides from the Roots of Echinacea Species. Journal of Natural Products, Vol.68, No.5, (April 2005), pp. 773-776, doi:10.1021/np040245f

Claros, B.M.G.; da Silva, A.J.R.; Vasconcellos, M.L.A.A.; de Brito, A.P.P. \& Leitao, G.G. (2000). Chemical constituents of two Mollinedia species. Phytochemistry, Vol.55, No.7, (December 2000), pp. 859-862, doi:10.1016/S0031-9422(00)00294-6

Continguiba, F.; Regasini, L.O.; Bolzani, V.S.; Debonsi, H.M.; Passerina G.D.; Barreto, R.M. ; Kato, M.J. \& Furlan, M. (2009). Piperamides and their derivatives as potential antitrypanosomal agents. Medicinal Chemistry Research, Vol.18, No.9, (December 2009), pp. 703-711, doi:10.1007/s00044-008-9161-9

Costa, S.S. \& Mors, W.B. (1981). Amides from Ottonia corcovadensis. Phytochemistry, Vol.20, No.6, (June 1981), pp. 1305-1305, doi:10.1016/0031-9422(81)80027-1

Das, B. ; Kashinatham, A. \& Srinivas, N.S. (1996). Alkamides and other constituents of Piper longum. Planta Medica, Vol.62, No.6, (December 1996), pp. 582-582

Déciga-Campos, M.; Rios, M.Y. \& Aguilar-Guadarrama, B. (2010). Antinociceptive effect of Heliopsis longipes extract and affinin in mice. Planta Medica, Vol.76, No.7, (May 2010), pp. 665-670, doi:10.1055/s-0029-1240658

Dominguez, X.A. ; Sánchez, H. ; Slim, J.S. ; Jakupovic, J. ; Lehmann, L. \& Bohlmann, F. (1987). Highly unsaturated amides from Sanvitalia oxymoides. Revista Latinoamericana de Quimica, Vol.18, pp. 114-115

Goda, Y.; Shibuya, M. \& Sankawa, U. (1987). Inhibitors of prostaglandin biosynthesis from Mucuna birdwoodiana. Chemical \& Pharmaceutical Bulletin, Vol.35, No.7, (July 1987), pp. $2675-2677$

Greger, H.; Hofer, O. \& Werner, A. (1985). New amides from Sphilanthes oleracea. Monatshefte fur Chemie, Vol.116, No.2, (February 1985), pp. 273-277, doi:10.1007/BF00798463

Greger, H.; Hofer, O. \& Werner, A. (1987a). Biosynthetically simple C 18 -alkamides from Achillea species. Phytochemistry, Vol.26, No.8, (December 1986), pp. 2235-2242, doi:10.1016/S0031-9422(00)84690-7

Greger, H.; Zdero, C. \& Bolhmann, F. (1987b). Pyrrole amides from Achillea ageratifolia. Phytochemistry, Vol.26, No.8, (December 1986), pp. 2289-2291, doi:10.1016/S00319422(00)84703-2

Greger, H. (1987c). Highly unsaturated isopentyl amides from Achillea wilhelmsii. Journal of Natural Products, Vol.50, No.6, (November 1987), pp. 1100-1107, doi:10.1021/np50054a015 
Greger, H. \& Hofer, O. (1989). Polyenic acid piperideides ando other alkamides from Achillea millefolium. Phytochemistry, Vol.28, No.9, (September 1989), pp. 2363-2368, doi:10.1016/S0031-9422(00)97985-8

Greger, H. \& Hofer, O. (1990). Alkamides and polyacetylenes: two different biogenetic trends in the European Achillea millefolium group. Planta Medica, Vol.56, No.6, (December 1990), pp. 531-532, doi:10.1055/s-2006-961094

Greger, H. \& Werner, A. (1990). Comparative HPLC analyses of alkamides within the Achillea millefolium group. Planta Medica, Vol.56, No.5, (October 1990), pp. 482-486, doi:10.1055/s-2006-961017

Greger, H.; Hadacek, F.; Hofer, O.; Wurz, G.; \& Zechner, G. (1993a). Different types of sulphur-containing amides from Glycosmis cf. chlorosperma. Phytochemistry, Vol.32, No.4, (March 1993), pp. 933-936, doi:10.1016/0031-9422(93)85232-G

Greger, H.; Zechner, G.; Hofer, O.; Hadacek, F.; \& Wurz, G. (1993b). Sulphur-containing amides from Glycosmis species with different antifungal activity. Phytochemistry, Vol.34, No.1, (August 1993), pp. 175-179, doi:10.1016/S0031-9422(00)90802-1

Greger, H.; Hofer, O.; Zechner, G.; Hadacek, F. \& Wurz, G. (1994). Sulphones derived from methylthiopropenoic acid amides from Glycosmis angustifolia. Phytochemistry, Vol.37, No.5, (November 1994), pp. 1305-1310, doi:10.1016/S0031-9422(00)90403-5

Greger, H. \& Hofer, O. (1996). Bioactive amides from Glycosmis species. Journal of Natural Products, Vol.59, No.12, (December 1996), pp. 1163-1168, doi:10.1021/np9604238

Ghosal, S.; Chakrabarti, D.K. (1988). Differences in phenolic and steroidal constituents between healthy and infected florets of Mangifera indica. Phytochemistry, Vol.27, No.5, (August 1987), pp. 1339-1343, doi:10.1016/0031-9422(88)80189-4

Herz, W. \& Kulanthaivel, P. (1985). An amide from Salmea scandens. Phytochemistry, Vol.24, No.1, (January 1985), pp. 173-174, doi:10.1016/S0031-9422(00)80830-4

Holzbach J.C. \& Lopes L.M.X. (2010). Aristolactams and Alkamides of Aristolochia gigantea. Molecules, Vol.15, No.12, (December 2010), pp. 9462-9472; doi:10.3390/molecules15129462

Horio, T.; Yoshida, K.; Kikuchi, H.; Kawabata, J. \& Mizutani, J. (1993). A phenolic amide from roots of Chenopodium album. Phytochemistry, Vol.33, No.4, (July 1993), pp. 807808, doi:10.1016/0031-9422(93)85278-Y

Huang, H.; Morgan, C.M.; Asolkar, R.N.; Kiovunen, M.E. \& Marrone, P.G. (2010). Phytotoxicity of Sarmentine Isolated from Long Pepper (Piper longum) Fruit. Journal of Agricultural and Food Chemistry, Vol.58, No.18, (August 2010), pp. 9994-10000, doi:10.1021/jf102087c

Hussain, S.F.; Gozler, B.; Shamma, M.; Gozler, T. (1982). Feruloyltyramine from Hypecoum. Phytochemistry, Vol.21, No.12, (December 1982), pp. 2979-2980, doi:10.1016/00319422(80)85081-3

Islam, T.; Hashidoko, Y.; Ito, T.; Tahara, S. (2004). Interruption of the homing events of phytopathogenic Aphanomyces cochlioides zoospores by secondary metabolites from nonhost Amaranthus gangeticus. Journal of Pesticide Science, Vol.29, No.1, (January 2004), pp. 6-14, doi:10.1584/jpestics.29.6

Johns, T. ; Graham, K. \& Towers, G.H.N. (1982). Molluscicidal activity of affinin and other isobutylamides from the Asteraceae. Phytochemistry, Vol.21, No.11, (November 1982), pp. 2737-2738, doi:10.1016/0031-9422(82)83110-5 
Kim, D.K.; Lim, J.P.; Kim, J.W.; Park, H.W. \& Eun, J.S. (2005). Antitumor and antiinflammatory constituents from Celtis sinensis. Archives of Pharmacal Research, Vol.28, No.1, (January 2005), pp. 39-43, doi:10.1007/BF02975133

Kobata, k.; Saito, K.; Tate, H.; Nashimoto, A.; Okuda, H.; Takemura, I.; Miyakawa, K.; Takahashi, M.; Iwai, K. \& Watanabe, T. (2010). Long-Chain N-Vanillyl-acylamides from. Journal of Agricultural and Food Chemistry, Vol.58, No.6, (March 2010), pp. 3627-3631, doi:10.1021/jf904280z

Kozukue, N.; Han, J.-S.; Kozukue, E.; Lee, S.-J.; Kim, J.-A.; Lee, K.-R.; Levin, C.E. \& Friedman, M. (2005). Analysis of Eight Capsaicinoids in Peppers and PepperContaining Foods by High-Performance Liquid Chromatography and Liquid Chromatography-Mass Spectrometry. Journal of Agricultural and Food Chemistry, Vol.53, No.23, (October 2005), pp. 9172-9181, doi:10.1021/jf050469j

Lazarevic, J.; Radulovic, N.; Zlatkovic. B. \& Palic, R. (2010). Composition of Achillea distans Willd. subsp. distans root essential oil. Natural Product Research, Vol.24, No.8, (May 2010), pp. 718-731, doi:10.1080/14786410802617292

Lalone, C.A.; Huang, N.; Rizshsky, L.; Yum, M.-Y.; Singh, N.; Hauck, C.; Nicolau, B.J.; Wurtele, E.S.; Kohut, M.L.; Murphy, P.A. \& Birt, D.F (2010). Enrichment of Echinacea angustifolia with Bauer alkylamide 11 and Bauer ketone 23 increased antiinflammatory potential through interference with COX-2 enzyme activity. Journal of Agricultural and Food Chemistry, Vol.58, No.15, (December 2010), pp. 8573-8584, doi:10.1021/jf1014268

Lee, S.W.; Rho, M.-Ch.; Nam. J.Y.; Lim, E.H.; Kwon, O.E.; Kim, Y.H.; Lee, H.S. \& Kim, Y.K. (2004). Guineensine, an acyl-CoA: cholesterol acyltransferase inhibitor, from the fruits of Piper longum. Planta Medica, Vol.70, No.7, (July 2004), pp. 678-679, doi:10.1055/s-2004-827193

Lee, S.W.; Kim, Y.K.; Kim, K.; Lee, H.S.; Choi, J.H.; Lee, W.S.; Jun, Ch.-D.; Park, J.H.; Lee, J.M.; \& Rho, M.-Ch. (2008). Alkamides from the fruits of Piper longum and Piper nigrum displaying potent cell adhesion inhibition. Bioorganic $\mathcal{E}$ Medicinal Chemistry Letters, Vol.18, No.16, (August 2008), pp. 4544-4546, doi:10.1016/j.bmcl.2008.07.045

Lee, S.W.; Rho, M.-Ch.; Park, H.R.; Choy, J.-H.; Kang, J.Y.; Lee, J.W. \& Kim, Y.K. (2006). Inhibition of Diacylglycerol Acyltransferase by Alkamides Isolated from the Fruits of Piper longum and Piper nigrum. Journal of Agricultural and Food Chemistry, Vol.54, No.26, (December) 2006, pp. 9759-9763, doi:10.1021/jf061402e

Li, N.; Wu, J.L.; Hasegawa, T.; Sakai, J.; Bai, L.M.; Wang, L.Y.; Kakuta, S.; Furuya, Y.; Ogura, H.; Kataoka, T.; Tomida, A.; Tsuruo, T. \& Ando, M. (2007) Bioactive polyketides from Peperomia duclouxii. Journal of Natural Products, Vol.70, No.6, (June 2007), pp. 998-1001, doi:10.1021/np070089n

Lv, A.L.; Zhang, N.; Sun, M.G.; Huang, Y.F.; Sun, Y.; Ma, H.Y.; Hua, H.M. \& Pei, Y.H. (2008). One new cinnamic imide derivative from the fruits of Tribulus terrestris. Natural Products Research, Vol.22, No.11, (July 2008), pp. 1007-1010, doi:10.1080/14786410701654867

López-Martínez, S.; Aguilar-Guadarrama, A.B. \& Rios, M.Y. (2011). Minor alkamides from Heliopsis longipes S.F. Blake (Asteraceae) fresh roots. Phytochemistry Letters, Vol.4, No.3, (September 2011), pp. 275-279, doi:10.1016/j.phytol.2011.04.014 
Martin, R. \& Becker, H. (1984). Sphilanthol related amides from Acmella ciliata. Phytochemistry, Vol.23, No.8, (August 1984), pp. 1781-1783, doi:10.1016/S00319422(00)83490-1

Martin, R. \& Becker, H. (1985). Amides and other constituents from Acmella ciliata. Phytochemistry, Vol.24, No.10, (October 1985), pp. 2295-3000, doi:10.1016/S00319422(00)83030-7

McFerren, M.A.; Cordova, D.; Rodriguez, E; \& Rauh, J.J. (2002). In vitro neuropharmacological evaluation of piperovatine, an isobutylamide from Piper piscatorum (Piperaceae). Journal of Ethnopharmacology, Vol.83, No.3, (December 2002), pp. 201-207, doi:10.1016/S0378-8741(02)00224-6

Meghvansi, M.K.; Siddiqui, S.; Khan, Md. H.; Gupta, V.K.; Vairale, M.G.; Gogoi, H.K.; \& Singh, L. (2010). Naga chilli: A potential source of capsaicinoids with broadspectrum ethnopharmacological applications. Journal of Ethnopharmacology, Vol.132, No.1, (October 2010), pp. 1-14, doi:10.1016/j.jep.2010.08.034

Michalet, S.; Cartier, G.; David, B.; Mariotte, A.M.; Dijoux-Franca, M.G.; Kaatz, G.W.; Stavri, M. \& Gibbons, S. (2007). N-Caffeoylphenalkylamide derivatives as bacterial efflux pump inhibitors. Bioorganic \& Medicinal Chemistry Letters, Vol.17, No.6, (March 2007), pp.1755-1758, doi:10.1016/j.bmcl.2006.12.059

Miyaichi, Y.; Nunomura, N.; Kawata, Y.; Kizu, H.; Tomimori, T.; Watanabe, T.; Takano, A. \& Malla, K.J. (2006). Studies on Nepalese crude drugs. XXVIII. Chemical constituents of Bhote Khair, the underground parts of Eskemukerjea megacarpum HARA. Chemical $\mathcal{E}$ Pharmaceutical Bulletin, Vol.54, No.1, (January 2006), pp. 136-138, doi:10.1248/cpb.54.136

Mizutani, M.; Hashidoko, Y.; Tahara, S. (1998). Factors responsible for inhibiting the motility of zoospores of the phytopathogenic fungus Aphanomyces cochlioides isolated from the non-host plant Portulaca oleracea. FEBS Letters, Vol.438, No.3, (November 1998), pp. 236-240, doi:10.1016/S0014-5393(98)01308-8

Molina, J.; Salgado, R.; Ramírez, E. \& del Río, R.E. (1996). Purely olefinic alkamides in Heliopsis longipes and Acmella (Spilanthes) oppositifolia. Biochemical Systematics and Ecology, Vol. 24, No.1, (January 1996), pp. 43-47, doi:10.1016/0305-1978(95)00099-2

Muhammad, I.; Zao, J.; Dumbar, D.C. \& Khan, I.A. (2002). Constituents of Lepidium meyenii 'maca'. Phytochemistry, Vol.59, No.1, (January 2002), pp. 105-110, doi:10.1016/S0031-9422(01)00395-8

Muller-Jakic, B.; Breu, W.; Probstle, A.; Redl, K.; Greger, H. \& Bauer, R. (1994). In vitro inhibition of cyclooxygenase and 5-lipoxygenase by alkamides from Echinaceae and Achillea species. Planta Medica, Vol.60, No.1, (February 1994), pp. 37-40, doi:10.1055/s-2006-959404

Muhlenbeck, U.; Kortenbusch, A. \& Barz, W. (1996). Formation of hydroxycinnamoylamides and $\alpha$-hydroxyacetovanillone in cell cultures of Solanum khasianum. Phytochemistry, Vol.42, No.6, (August 1996), pp. 1573-1579, doi:10.1016/0031-9422(96)00173-2

Navickiene, H.M.D.; Alecio, A.C.; Kato, M.J.; Bolzani, V.S.; Young, M.C.M.; Cavalheiro, A.J. \& Furlan, M. (2000). Antifungal amides from Piper hispidum and Piper tuberculatum. Phytochemistry., Vol.55, No.6, (November 2000), pp. 621-626, doi:10.1016/S00319422(00)00226-0 
Navickiene, H.M.D. \& Lopes, L.M.X. (2001). Alkamides and phenethyl derivatives from Aristolochia gehrtii. Journal of the Brazilian Chemical Society, Vol. 12, No.4, (August 2001), pp. 467-472, doi:10.1590/S0103-50532001000400004

Nishioka, T.; Watanabe, J.; Kawabata, J. \& Niki, R. (1997). Isolation and activity of N-pcoumaroyltyramine, an $\alpha$-glucosidase inhibitor in Welsh onion (Allium fistulosum). Bioscience, Biotechnology, and Biochemistry, Vol.61, No.7, (July 1997), pp. 1138-1141, doi:10.1271/bbb.61.1138

Otsuka, H.; Ito, A.; Fujioka, N.; Kawamata, K.I.; Kasai, R.; Yamasaki, K. \& Satoh, T. (1993). Butenolides from Sinomenium acutum. Phytochemistry, Vol.33, No.2, (May 1993), pp. 389-392, doi:10.1016/0031-9422(93)85525-V

Pandey, V.; Chopra, M. \& Agrawal, V. (2011). In vitro isolation and characterization of biolarvicidal compounds from micropropagated plants of Spilanthes acmella. Parasitol Research, Vol.108, No.2, (February 2011), pp. 297-304, doi:10.1007/s00436010-2056-y

Patnaik, T.; Dey, R.K. \& Gouda, P. (2008). Antimicrobial activity of friedelan-3- $\beta$-ol and trans-N-caffeoyltyramine isolated from the root of Vitis trifolia. Asian Journal Chemistry, Vol.20, No.1, pp. 417-421

Patra, A. \& Ghosh, A. (1974). Amides of Piper chaba. Phytochemistry, Vol.13, No.12, (December 1974), pp. 2889-2890, doi:10.1016/0031-9422(74)80272-4

Perry, N.B.; van Klink, J.W.; Burgess E.J. \& Parmenter, G.A. (2000). Alkamide levels in Echinaceae purpurea: effects of processing, drying and storage. Planta Medica, Vol.66, No.1, (February 2000), pp. 54-56, doi:10.1055/s-2000-11111

Pedersen, H.A.; Steffenses S.K.; Christopherses C.; Mortensen, A.G.; Jorgensen L.N.; Niveyro, S.; de Troiani R.M.; Rodriguez-Enriquez, R.J.; Barba-de la Rosa, A.P. \& Fomsgaard, I.S. (2010). Synthesis and Quantitation of Six Phenolic Amides in Amaranthus spp. Journal of the Agricultural and Food Chemistry, Vol.58, No.10, (May 2010), pp. 6306-6311, doi:10.1021/jf100002v

Pereira, C.A.B.; Oliveira, F.M.; Conserva, L.M.; Lemos, R.P.L. \& Andrade, E.H.A. (2007). Cinnamoyltyramine derivatives and other constituents from Sparattanthelium tupiniquinorum (Hernandiaceae). Biochemical Systematics and Ecology, Vol.35, No.9, (September 2007), pp. 637-639, doi:10.1016/j.bse.2007.03.014

Perry, N.B.; van Klink, J.W.; Burgess E.J. \& Parmenter, G.A. (1997). Alkamide levels in Echinaceae purpurea: a rapid analytical method revealing differences among roots, rhizomes, steams, leaves and flowers. Planta Medica, Vol.63, No.1, (February 1997), pp. 58-62, doi:10.1055/s-2006-957605

Rao, V.R.S.; Suresh, G.; Banu, K.S.; Raju, S.S.; Vishnu vardhan, M.V.P.S.; Ramakrishna, S. \& Rao, M. (2011). Novel dimeric amide alkaloids from Piper chaba Hunter: isolation, cytotoxic activity, and their biomimetic synthesis. Tetrahedron, Vol.67, No.10, (March 2011), pp. 1885-1892, doi:10.1016/j.tet.2011.01.015

Ramsewak, R.S.; Erickson, A.J. \& Nair, M.G. (1999). Bioactive $N$-isobutylamides from the flower buds of Spilanthes acmella. Phytochemistry, Vol.51, No.6, (July 1999), pp. 729_ 732, doi:10.1016/S0031-9422(99)00101-6

Rios-Chavez, P.; Ramirez-Chavez, E.; Armenta-Salinas, C. \& Molina-Tores, J. (2003). Acmella radicans var. radicans: in vitro culture establishment and alkamide content. In Vitro Cellular \& Developmental Biology - Plant. Vol.39, No.1, (January-February 2003), pp. 37-41, doi:10.1079/IVP2002354 
Rios, M.Y.; Aguilar-Guadarrama, A.B. \& Gutiérrez, M.C. (2007). Analgesic activity of affinin, an alkamide from Heliopsis longipes (Compositae). Journal of Ethnopharmacology, Vol.110, No.2, (March 2007), pp. 364-367, doi:10.1016/j.jep.2006.09.041

Rosario, S.L.; da Silva, A.J. \& Parente, J.P. (1996). Alkamides from Cissampelos glaberrima. Planta Medica, Vol.62, No.4, (August 1996), pp. 376-377, doi:10.1055/s-2006-957913

Ross, S.A.; Al-Azeib, M.A.; Krishnaveni, K.S.; Fronczek, F.R. \& Burandt, Ch.L. (2005). Alkamides from the Leaves of Zanthoxylum syncarpum. Journal of Natural Products, Vol.68, No.8, (August 2005), pp. 1297-1299, doi:10.1021/np0580558

Rucker, G.; Breitmaier, E.; Zhang, G.L. \& Mayer, R. (1994). Alkaloids from Dactylicapnos torulosa. Phytochemistry, Vol.36, No.2, (May 1994), pp. 519-523, doi:10.1016/S00319422(00)97106-1

Saadali, B.; Boriky, D.; Blaghen, M.; Vanhaelen, M. \& Talbi, M. (2001). Alkamides from Artemisia dracunculus. Phytochemistry, Vol.58, No.7, (December 2001), pp. 1083-1086, doi:10.1016/S0031-9422(01)00347-8

Sailaja, R. \& Setty, O.H. (2006). Protective effect of Phyllanthus fraternus against allyl alcoholinduced oxidative stress in liver mitochondria. Journal of Ethnopharmacology, Vol.105, No.1-2, (April 2006), pp. 201-209, doi:10.1016/j.jep.2005.10.019

Sakakibara, I.; Katsuhara, T.; Ikeya, Y.; Hayashi, K. \& Mitsuhashi, H. (1991). Cannabisin-A, an arylnaphthalene lignanamide from fruits of Cannabis sativa. Phytochemistry, Vol.30, No.9, (September 1991), pp. 3013-3016, doi:10.1016/S0031-9422(00)98242-6

Schulthess, B.H; Giger, E. \& Baumann T.W. (1991). Echinaceae: anatomy, phytochemical patern, and germination of the achene. Planta Medica, Vol.57, No.4, (August 1991), pp. 384-388, doi:10.1055/s-2006-960123

Senchina, D.S.; Wu, L.; Flinn, G.N.; Konopa, D.L.; McCoy, J.-A.; Widrelechner, M.P.; Wurtele, E.S. \& Kohut, M.L. (2006). Year-and-a-half old, dried Echinaceae roots retain cytokine-modulating capabilities in an in vitro human older adult model of influenza vaccination. Planta Medica, Vol.72, No.15, (December 2006), pp. 12071215, doi:10.1055/s-2006-957078

Sittie, A.A.; Lemmich, E.; Olsen, C.E.; Hviid, L. \& Chistensen, S.B. (1998). Alkamides from Phyllanthus fraternus. Planta Medica, Vol.64, No.2, (March 1998), pp. 192-193, doi:10.1055/s-2006-957405

Subehan; Usia, T.; Kadota, S. \& Tezika, Y. (2006). Mechanism-based inhibition of human liver microsomal cytochrome P450 2D6 (CYP2D6) by alkamides of Piper nigrum. Planta Medica, Vol. 72, No.6, (April 2006), pp. 527-532, doi:10.1055/s-2006-931558

Tanaka, H.; Nakamura, T.; Ichino, K. \& Ito, K. (1989). A phenolic amide from Actinodaphne longifolia. Phytochemistry, Vol.28, No.9, (September 1989), pp. 2516-2517, doi:10.1016/S0031-9422(00)98022-1

Tofern, B.; Manna, P.; Kalogaa, M.; Jenett-Siemsa, K.; Witte, L. \& Eicha, E. (1999). Aliphatic pyrrolidine amides from two tropical convolvulaceous species. Phytochemistry, Vol.52, No.8, (December 1999), pp. 1437-1441, doi:10.1016/S00319422(99)00245-9

Tseng, C.F.; Iwakami, S.; Mikajiri, A.; Shibuya, M.; Hanaoka, F.; Ebizuka, Y.; Padmawinata, K. \& Sankawa, U. (1992). Inhibition of in vitro prostaglandin and leukotriene biosyntheses by cinnamoyl- $\beta$-phenethylamine and $N$-acyldopamine derivatives. Chemical \& Pharmaceutical Bulletin, Vol.40, No.2, (February 1992), pp. 396-400

Turnock, J.; Cowan, S.; Watson, A.; Bartholomew, B.; Bright, C.; Latif, Z.; Sarker, S.D.; Nash, R.J. (2001). N-trans-feruloyltyramine from two species of the Solanaceae. Biochemical 
Systematics and Ecology, Vol.29, No.2, (February 2001), pp. 209-211, doi:10.1016/S0305-1978(00)00030-2

Woelkar, K.; Xu, W.; Pei, Y.; Makriyannis, A.; Picone, R.P. \& Bauer, R. (2005). The endocannabinoid system as a target for alkamides from Echinaceae angustifolia roots. Planta Medica, Vol.71, No.8, (August 2005), pp. 701-705, doi:10.1055/s-2005-871290

Wu, P.L.; Wu, T.S.; He, C.X.; Su, C.H. \& Lee, K.H. (2005). Constituents from the stems of Hibiscus taiwanensis. Chemical \& Pharmaceutical Bulletin, Vol.53, No.1, (January 2005), pp. 56-59, doi:10.1248/cpb.53.56

Wu, L.C.; Fan, N.C.; Lin, M.H.; Chu, I.R.; Huang, S.J.; Hu, C.Y. \& Han, S.Y. (2008). Antiinflammatory effect of spilanthol from Spilanthes acmella on murine macrophage by down-regulating LPS-induced inflammatory mediators. Journal of the Agricultural and Food Chemistry, Vol.56, No.7, (March 2008), pp. 2341-2349, doi:10.1021/jf073057e

Wu, T.-S..; Chang, F.-C. \& Wu, P.-L. (1995). Flavonoids, amidosulfoxides and an alkaloid from the leaves of Glycosmis citrifolia. Phytochemistry, Vol.39, No.6, (August 1995), pp. 1453-1457, doi:10.1016/0031-9422(95)00171-3

Yue, J.M.; Xu, J.; Zhao, Y.; Sun, H.D. \& Lin, Z.W. (1997). Chemical components from Ceratostigma willmottianum. Journal of Natural Products, Vol.60, No.10, (October 1997), pp. 1031-1033, doi:10.1021/np97004

Zacares, L.; Lopez-Gresa, M.P.; Fayos, J.; Primo, J.; Belles, J.M. \& Conejero, V. (2007). Induction of $p$-coumaroyldopamine and feruloyldopamine, two novel metabolites, in tomato by the bacterial pathogen Pseudomonas syringae. Mol. Plant-Microbe Interact., Vol.20, No.11, (November 2007), pp. 1439-1448, doi:10.1094/MPMI-20-111439

Zhao, J.; Muhammad, I.; Dunbar, D.Ch.; Mustafa, J. \& Khan, I.A. (2005). New Alkamides from Maca (Lepidium meyenii). Journal of the Agricultural and Food Chemistry, Vol.53, No.3, (January 2005), pp. 690-693, doi:10.1021/jf048529t 


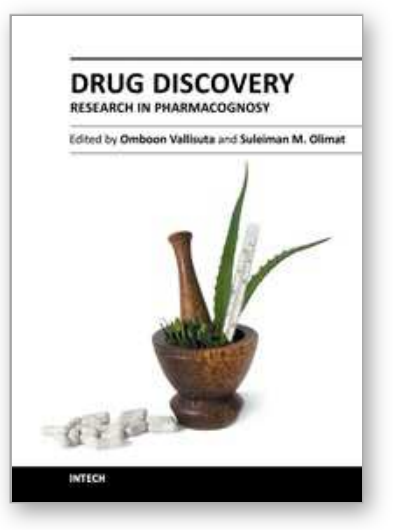

\author{
Drug Discovery Research in Pharmacognosy \\ Edited by Prof. Omboon Vallisuta
}

ISBN 978-953-51-0213-7

Hard cover, 244 pages

Publisher InTech

Published online 16, March, 2012

Published in print edition March, 2012

This book, Drug Discovery Research in Pharmacognosy provides a full picture of research in the area of pharmacognosy with the goal of drug discovery from natural products based on the traditional knowledge or practices. Several plants that have been used as food show their potential as chemopreventive agents and the claims of many medicinal plants used in traditional medicine are now supported by scientific studies. Drug Discovery Research in Pharmacognosy is a promising road map which will help us find medicine for all!

\title{
How to reference
}

In order to correctly reference this scholarly work, feel free to copy and paste the following:

María Yolanda Rios (2012). Natural Alkamides: Pharmacology, Chemistry and Distribution, Drug Discovery Research in Pharmacognosy, Prof. Omboon Vallisuta (Ed.), ISBN: 978-953-51-0213-7, InTech, Available from: http://www.intechopen.com/books/drug-discovery-research-in-pharmacognosy/natural-alkamidespharmacology-chemistry-and-distribution

\section{INTECH}

open science | open minds

\section{InTech Europe}

University Campus STeP Ri

Slavka Krautzeka 83/A

51000 Rijeka, Croatia

Phone: +385 (51) 770447

Fax: +385 (51) 686166

www.intechopen.com

\section{InTech China}

Unit 405, Office Block, Hotel Equatorial Shanghai

No.65, Yan An Road (West), Shanghai, 200040, China

中国上海市延安西路65号上海国际贵都大饭店办公楼 405 单元

Phone: +86-21-62489820

Fax: $+86-21-62489821$ 
(C) 2012 The Author(s). Licensee IntechOpen. This is an open access article distributed under the terms of the Creative Commons Attribution 3.0 License, which permits unrestricted use, distribution, and reproduction in any medium, provided the original work is properly cited. 